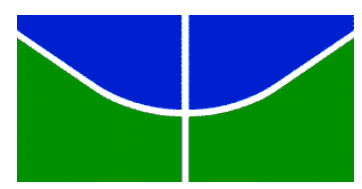

Universidade de Brasília Instituto de Ciências Biológicas

Pós-Graduação em Botânica

Mestrado em Botânica

Variação natural de folato em sementes de feijão-caupi [Vigna unguiculata (L.) Walp.] e sua correlação com a expressão do gene Vugch1 (GTP ciclohydrolase 1)

CRISTINA PIMENTEL DO NASCIMENTO

Orientador: Dr. Francisco José Lima Aragão

Brasília, 2016 


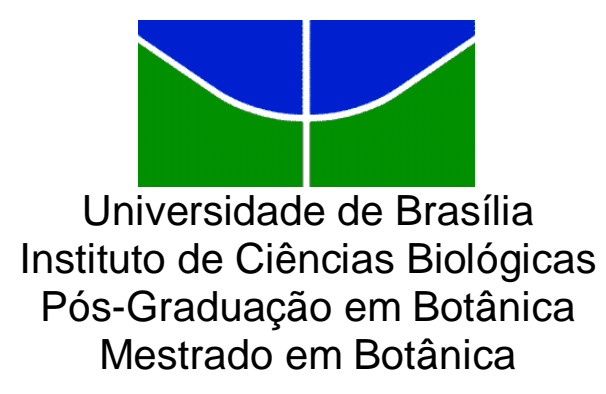

\title{
Variação natural de folato em sementes de feijão-caupi [Vigna unguiculata (L.) Walp.] e sua correlação com a expressão do gene Vugch1 (GTP ciclohydrolase 1)
}

\author{
CRISTINA PIMENTEL DO NASCIMENTO
}

Orientador: Dr. Francisco José Lima Aragão

Dissertação de Mestrado apresentado ao Programa de Pós Graduação em Botânica da Universidade de Brasília para a obtenção do título de Mestre em Botânica.

Brasília, 2016 


\section{DEDICO}

A minha mãe Rosalina, ao meu pai Osmundo, a minha irmã Patrícia, ao meu irmão Eduardo que sempre me deram forças e que nunca me deixaram desistir, sempre me dizendo palavras de força e incentivo com muito carinho. Sempre foram luz na minha vida. Dedico também ao meu namorado Atila. Deus foi muito maravilho comigo por ter colocado todos vocês em meu caminho.

"A família é um refúgio num mundo sem coração." Christopher Lasch 


\section{AGRADECIMENTOS}

Primeiramente gostaria de agradecer a Deus e Nossa Senhora por terem me concedido o milagre da vida e por sempre intercederem na minha vida, guiando, abençoando os meus passos e meus estudos. Sem eles a minha vida não teria o menor sentido.

Aos meus pais Rosalina e Osmundo que sempre me incentivaram a estudar e sempre querer algo melhor para minha vida, graças a eles eu tive uma ótima educação e exemplos de vida, de força e superação. São meus heróis. Meu porto seguro. Obrigada por toda a dedicação que tiveram comigo e meus irmãos.

Aos meus irmãos Patrícia e Eduardo que são verdadeiros presentes de Deus para minha vida, sempre estivemos juntos sendo cúmplices uns dos outros. Verdadeiros amigos. Obrigada por todo apoio.

Ao meu amor - Atila - que é além de tudo um grande amigo e que por todo esse período do mestrado esteve junto a mim aguentando as minhas chatices, sempre muito paciente e compreensivo. Sua presença em minha vida foi, é e sempre será muito importante. Obrigada por ter alegrado sempre os meus dias.

Aos meus familiares, minhas avós, meus tios, minhas tias, meus primos, minhas primas Mayanne, Thatianne, Tatyelle, Mayellen, Suellen, Silvaneide, a princesinha Maria Clara que chegou para iluminar os nossos dias e a minha cunhada Jaqueline que também esteve sempre junto. Pessoal desculpa não escrever o nome de cada um de vocês, mas é que somos muitos. Todos são muito importantes.

Ao Francisco Aragão por ter aceitado ser meu orientador e a todos os amigos do laboratório aos antigos e aos novos. O meu muito obrigada aos queridos Abdul, Angélica, Cristiane, Elsa, Heitor, Maria Laine, Nayanne, Lídia, Natália, Pedro e Tomas.

Aos amigos Heloíza Helena, Rebeca, Rômulo, Reneida e Ana Carolina que acompanharam minha trajetória e sempre me disseram palavras de incentivo e força. Valeu!

Aos secretários do departamento de botânica, Eduardo Barreto e Sarah Lee que sempre tiveram muita paciência comigo e sempre estavam prontos para tirar minhas dúvidas, ajudar e para bater um papinho.

Ao professor Paulo Câmara que não me deixou desanimar no momento de maior dificuldade. 
Aos participantes de minhas bancas Andrea Rachel, Glaucia Cabral, Thaís Cipriano e ao professor Tomas Willians que me ajudaram a construir este trabalho que eu fiz com muito carinho e amor.

A Joseane Padilha estatística da EMBRAPA Cenargen por ter me ajudado a fazer as análises estatísticas do trabalho.

As pedras no caminho foram muitas, as dificuldades foram sempre vencidas, cada vez fiquei mais forte e nada disso teria sido possível sem o apoio e ajuda de cada um de vocês, sem vocês teria sido muito mais difícil. De coração, o meu muito obrigada. Muita luz para todos. 
"A esperança é aquela coisa com penas, que pousa na alma, e canta a melodia sem palavras, e nunca para." Emily Dickinson 


\section{LISTA DE ABREVIATURAS}

ADCS - aminodeoxicorismato

ANVISA - Agência de Vigilância Sanitária

DFE - Dietary Folate equivalentes

DHM - dihidromonapteridina

DHN - dihidroneopterina aldolase

DHN-PPP - dihidroneopterina trifosfato

Genbank - base de dados de sequências genéticas

Glu - glutamato

GTP - guanosina trifosfato

GTPCH1 - GTP ciclohydrolase 1

HMDHP-PP - hidroximetildihidropterina pirofosforilada

HMDP- hidroximetildihidropteroato

MEGA - Molecular Evolutionary Genetics Analysis

pABA - Ácido pteroilglutâmico

$\mathrm{pb}$ - pares de base

PCR - reação em cadeia da polimerase

qRT-PCR - PCR quantitativo em tempo real

RDC - Resolução de Diretoria Colegiada

RT-PCR - reação da transcriptase reversa

THF - Tetrahidrofolato

USDA - Departamento de Agricultura dos Estados Unidos 


\section{Sumário}

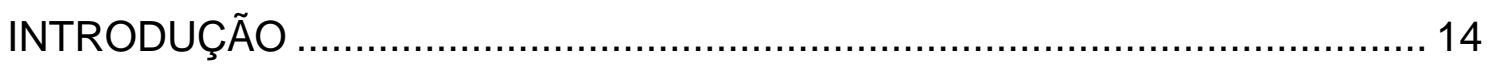

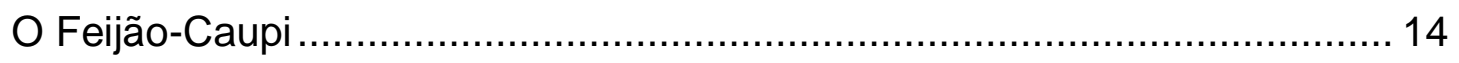

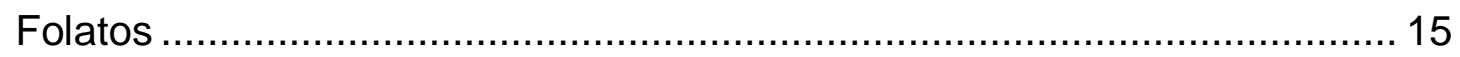

Biossíntese de folatos em plantas......................................................... 19

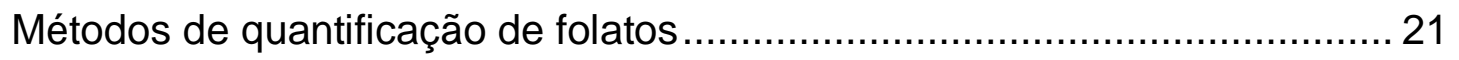

Aumento do teor de folatos em plantas por meio de biotecnologia ................ 22

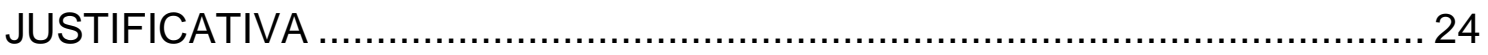

OBJETIVO

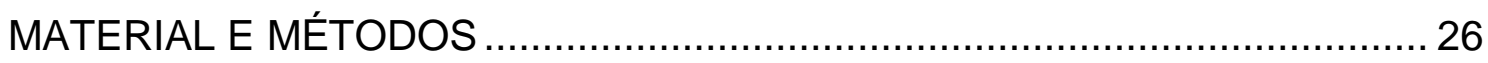

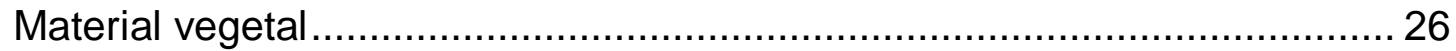

Extração de folatos totais de sementes maduras de feijão-caupi .................. 27

Clonagem e sequenciamento de fragmentos dos genes da gch1 e alphaEF1.

Extração de RNA de sementes imaturas após antese ................................. 28

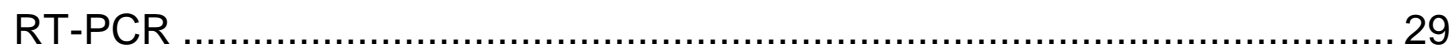

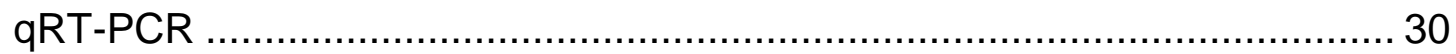

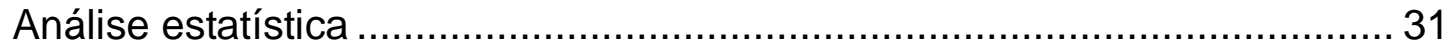

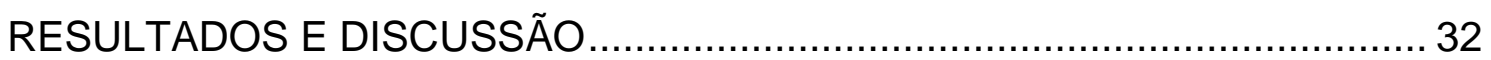

Quantificação do teor de folatos em feijão-caupi ......................................... 32

Obtenção de fragmentos dos genes gch1 e alphaEF1 de $V$. unguiculata..... 37

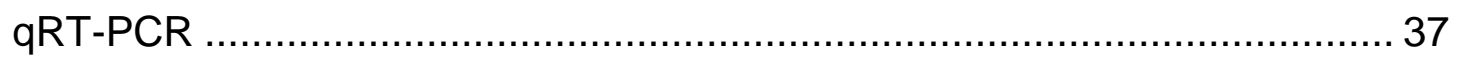

Correlação da expressão do gene $g c h /$ com o teor de folatos ...................... 40

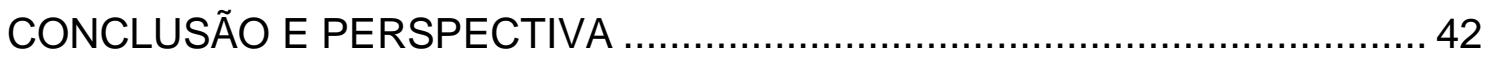

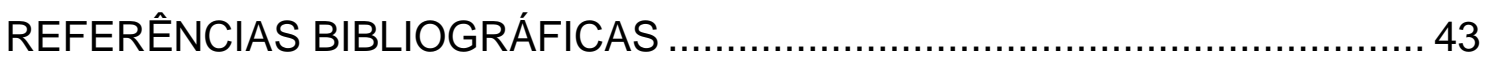

ANEXO 1 - referente a Vigna unguiculata elongation factor 1-alpha (ef1-a) mRNA, partial CDs (número de acesso GenBank: KM886568.1) ....................51 
ANEXO 2 - referente a Vigna unguiculata GTP cyclohydrolase 1 (gch1) mRNA (número de acesso GenBank: KM886567.1) 


\section{ÍNDICE DE FIGURAS E TABELAS}

Figura 1: Estrutura química da forma monoglutamilada do tetrahidrofolato (THF) composta por um anel pteridinio e pelos ácidos paraaminobenzóico (pABA) e glutamato, podendo ter uma calda com até oito resíduos ligados ao primeiro glutamato (Lima et al., 2003)...

Tabela 1: Nomenclatura e funções bioquímicas das diversas formas de folatos (Lima et al., 2003) 16

Figura 2: Via de síntese de folato em plantas. As pterinas estão em azul, no citosol ocorre a conversão da guanosina trifosfato (GTP) para hidroximetildihidropterina (HMDHP) através da ação da enzima GTP ciclohidrolase 1 (GTPCH1). A via de síntese de $p$-aminobenzoato é mostrada em verde ocorrendo no cloroplasto, o corismato é convertido em para ácido para-aminobenzoico (pABA) pela ação da enzima aminodeoxicorismato (ADCS). É na mitocôndria que a produção do tetrahidrofolato (THF) acontece. $\mathrm{P}$ refere-se à monofosfato, PP a pirofosfato e PPP a trifosfato (adaptado de Quinlivan et al., 2003) .20

Tabela 2: Genótipos de feijão-caupi analisadas para a determinação de teores de folatos totais 26

Tabela 3: Primers utilizados na análise de RTPCR .29

Tabela 4: Lista de primers utilizados na análise de qRTPCR. 30

Figura 3: A) cultivares em fase de desenvolvimento para posteriormente gerarem as vagens a serem coletadas nos diferentes dias de maturação após a 
antese. B) vagens em diferentes dias de maturação sendo contados a partir dos dias de desenvolvimento após a antese.

Tabela 5: Análise do teor de folato ( $\mu \mathrm{g}$ de folato / $100 \mathrm{~g}$ de semente) em 50 genótipos de feijão caupi

Figura 4: Nível de expressão relativa do gene gch1 em sementes imaturas de 5 cultivares de feijão-caupi 10, 15, 2025 dias após a antese. A comparação entre as médias observadas em cada dia, para uma mesma cultivar, mostrou serem estatisticamente diferentes, exceto os dias 15 e 20 para CE06 $(\mathrm{P}<0,05$; $n=3)$

Figura 5: Expressão relativa do gene Vugch1 em sementes de 50 genótipos de feijão-caupi 20 dias após a antese (gráfico superior) e teores de folatos totais em sementes maduras (gráfico inferior). Média \pm erro padrão $(n=9)$ 39

Figura 6: Análise da correlação entre o nível de expressão do gene gch1 e a quantidade de folatos totais em sementes imaturas com 20 dias após a antese. Coeficiente de correção linear = 0,955 . .40 


\section{RESUMO}

No Brasil, o feijão-caupi é considerado uma das espécies alimentares mais cultivadas no Norte e Nordeste. Constitui um dos mais importantes componentes da dieta alimentar proteica e energética das populações rurais dessas regiões, é citada como fonte de folatos uma vitamina pertencente ao grupo vitaminas hidrossolúveis do complexo B9. As moléculas de folatos são formadas por três grupos funcionais: pterina, ácido para-aminobenzoico (pABA) e de um a oito resíduos de gluatamato. Em plantas, a primeira reação de produção de folatos é catalisada pela ação da gch1, que fornece instruções para a produção da enzima GTP ciclohidrolase 1, esta enzima está envolvida na primeira etapa da produção de folatos em plantas, produzindo a pterina, enquanto o precursor de pABA é sintetizado no cloroplasto. $O$ objetivo do presente trabalho foi a quantificação do teor de folatos em 50 genótipos de feijão-caupi [Vigna unguiculata (L.) Walp.], disponibilizados pelo banco de germoplasma da Embrapa Meio-Norte (Piauí, Brasil), International Institute of Tropical Agriculture (IITA) (Oyo State, Nigéria) e Ahmadu Bello University (Zária, Nigéria). Além disso, estudou-se a correlação dos teores de folatos e os níveis de expressão do gene Vugch1, que codifica para a GTP ciclohidrolase 1, enzima considerada chave na rota de síntese de pterinas, um precursor de folatos. Os genótipos foram plantados em casa de vegetação e as sementes imaturas foram coletadas com 10, 15, 20 e 25 dias após a antese. O maior nível de expressão de Vugch1 foi observado em sementes coletadas 20 dias após a antese. Com as análises realizadas em sementes maduras constatouse que houve uma variação no teor de folatos entre 177 a $780 \mu \mathrm{g} / 100 \mathrm{~g}$ (Pingo de Ouro e Yarwaja, respectivamente) nos genótipos estudados, valores estes bem acima dos encontrados na literatura para o feijão-caupi. Confirmou-se a correlação entre a expressão do gene Vugch1 e a variação no teor de folatos. Com esses resultados, existe a possibilidade de avaliar os genótipos mais adequados para utilização de programas de melhoramento genético com variedades de feijão-caupi que possuam maior concentração no teor de folato.

Palavras chave: feijão-caupi, folato, acido fólico, correlação, expressão do gene gchl 


\begin{abstract}
In Brazil, the cowpea is considered one of the most cultivated food species in the North and Northeast. It is one of the most important components of protein and energy diet of rural populations in these regions, is cited as a source of folate a vitamin belonging to the water-soluble vitamins group B9 complex. Folate molecules consist of three functional groups: pterin, para-aminobenzoic acid (pABA) and one to eight residues of gluatamate. In plants, the first folate production is catalyzed by the action of gch1, which provides instructions for the production of the enzyme GTP cyclohydrolase 1, the enzyme is involved in the first step of folate production in plants producing pterin as the precursor pABA is synthesized in the chloroplast. The aim of this study was to quantify the folate content in 50 cultivars of cowpea [Vigna unguiculata (L.) Walp.] provided by the germplasm bank of Embrapa Meio Norte (Piauí, Brazil), International Institute of Tropical Agriculture (IITA) (Oyo State, Nigeria) and Ahmadu Bello University (Zaria, Nigeria). In addition, the correlation of folate content and the expression of the gene Vugch1 was studied. Vugch1 codes for GTP cyclohydrolase 1, a key enzyme for the pterins pathway. The cultivars were planted in the greenhouse and the immature seeds were harvested 10, 15, 20 and 25 days after anthesis. The highest expression level of Vugch1 gene was observed 20 days after anthesis. It was ibserved a variation in the folate content in mature seeds ranging from 177 to $780 \mu \mathrm{g} / 100 \mathrm{~g}$ (Pingo de Ouro and Yarwaja respectively). It was confirmed the correlation between the expression of the Vugch1 gene and folate content. With these results, it is possible to perform appropriate genotype crosses in order to generate new elite varieties with high folate content.
\end{abstract}

Keywords: cowpea, folate, folic acid, correlation, gch1 gene expression 


\section{INTRODUÇÃO}

\section{O Feijão-Caupi}

O feijão-caupi [Vigna unguiculata (L.) Walp.] tem a sua origem no continente africano, sendo introduzido na América Latina na segunda metade do século XVI. No Brasil, foi introduzido primeiramente no estado da Bahia, disseminando-se pela região Nordeste e posteriormente para as demais regiões do país (Freire Filho et al., 2011).

Pertence à família Fabaceae que contém outras importantes espécies cultivadas, dentre essas, as espécies $V$. unguiculata (feijão-caupi), $V$. radiata (feijão-mungo-verde) e V. mungo (feijão-mungo-preto) (Alves et al., 2007). É uma espécie autógama, herbácea e anual, considerada rústica e de alto potencial produtivo, características que conferem grande valor à cultura. Seus nomes populares são: feijão-caupi, feijão-de-corda e feijão-macassar (na Região Nordeste), feijão-da-estrada, feijão-de-praia e feijão-da-colônia (na Região Norte), feijão-miúdo e/ou feijão-fradinho (na Região Sul) (Freire Filho et al., 2005; Freire Filho et al., 2011). Tem um desenvolvimento vegetativo que dura em média de 23 a 43 dias e um desenvolvimento reprodutivo caracterizado após os 43 dias quando então surgem as vagens. A colheita das vagens começa cerca de 90 dias após a sua semeadura (Neves et al., 2009). É uma leguminosa de grande importância para a nutrição e os meios de subsistência de milhões de pessoas de países menos desenvolvidos dos trópicos podendo ser consumida na forma de vagens, grãos secos, grãos verdes ou frescos, farinha para acarajé, além de outras formas de preparo, sendo possível produzir um cardápio variável de mingaus e caldos; além de enriquecer com proteínas as massas alimentícias para a fabricação de pães, biscoitos, entre outros produtos (Melo et al., 2010).

A planta de feijão-caupi, faz simbiose com bactérias do gênero Rhizobium, constituindo um importante fixador de nitrogênio atmosférico, 
podendo ser introduzido em solos com baixos teores de matéria orgânica (Andrade Júnior et al., 2007). É uma cultura rústica, sendo pouco exigente em fertilidade de solos, tolerante a altas temperaturas e à seca. As temperaturas para seu desenvolvimento giram em torno de $18{ }^{\circ} \mathrm{C}$ a $34^{\circ} \mathrm{C}$ (Passos et al., 2007).

No Brasil, o feijão-caupi é considerado uma das espécies alimentares mais cultivadas no Norte e Nordeste. Constituindo-se um dos mais importantes componentes da dieta alimentar proteica e energética das populações rurais dessas regiões, fornecendo quantidades relativas de fósforo, ferro, tiamina, riboflavina e niacina (Freire Filho et al., 2005; Andrade Júnior et al., 2007; Cravo \& Souza, 2007; Menezes et al., 2007; Silva et al., 2011).

É amplamente cultivada na África, América Latina, Europa, Sudeste da Ásia e Sudeste de Regiões da América do Norte, com uma produção anual mundial de cerca de 3,9 milhões de toneladas (Ivo et al., 2008; Citadin et al., 2013). No Brasil os estados que se destacam na produção de feijão-caupi são Maranhão, Bahia, Piauí, Ceará e Rio Grande do Norte. Nestes estados e em toda a Região Nordeste esta cultivar é uma importante fixadora de mão de obra, sendo cultivado por pequenos, médios e grandes produtores (Vilarinho \& Freire Filho, 2005; Uchoa et al., 2007; Freire Filho et al., 2007; Frota et al., 2009).

\section{Folatos}

Nos estudos iniciais os cientistas acreditavam que a deficiência de folatos e anemia eram a mesma condição. Uma observação chave feita pela pesquisadora Lucy Wills, em 1928, levou à identificação de folatos como os nutrientes necessários para prevenir anemia durante a gravidez. Em 1941, os pesquisadores Mitchell Snell e Williams isolaram folatos de folha de espinafre assim surgindo à denominação para a vitamina. Esta vitamina foi sintetizada na forma cristalina em 1943 por Bob Stokstad, e em 1945 por Angier (Vásquez \& Suarez-Obando, 2015). As moléculas de folatos são tripartidas compreendendo em um anel pteridinio, pelos ácidos paraaminobenzóico (pABA) e glutâmico (Quinlivan et al., 2003) (Figura 1). 


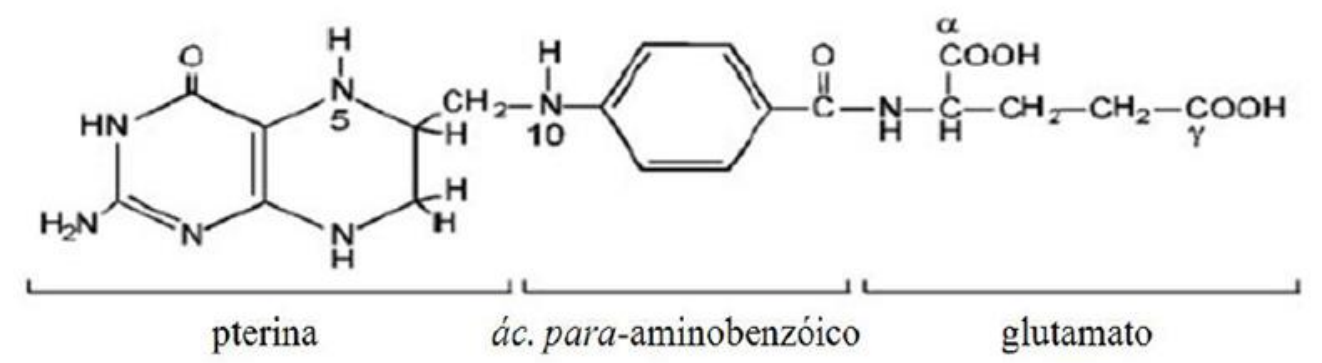

Figura 1: Estrutura química da forma monoglutamilada do tetrahidrofolato (THF) composta por um anel pteridinio e pelos ácidos paraaminobenzóico (pABA) e glutamato, podendo ter uma calda com até oito resíduos ligados ao primeiro glutamato (Lima et al., 2003).

Apesar do ácido pteroilglutâmico (pterina mais pABA) (Figura 1) ser a estrutura química comum aos folatos, ele não é o principal congênere nos alimentos, nem a coenzima ativa no metabolismo intracelular. Os folatos encontrados nos alimentos estão, predominantemente, na forma de poliglutamatos (Krishnaswamy \& Madhavan, 2001; Lima-Pallone et al., 2008a) (Tabela 1).

Tabela 1: Nomenclatura e funções bioquímicas das diversas formas de folatos (Lima et al., 2003).

\begin{tabular}{|c|c|c|c|c|}
\hline Composto & Congênere & Radical & Posição & Função \\
\hline Metiltetraidrofolato & $\mathrm{CH}_{3} \mathrm{H}_{4}$ PteGlu & $-\mathrm{CH}_{3}$ & N5 & $\begin{array}{l}\text { * Conversão de } \\
\text { homocisteína a } \\
\text { metionina } \\
{ }^{*} \text { Conversão de } \\
\text { serina a glicina }\end{array}$ \\
\hline Ácido folínico & $5-\mathrm{CHOH}_{4}$ PteGlu & $-\mathrm{CHO}$ & N5 & $\begin{array}{l}{ }^{*} \text { Síntese de } \\
\text { purinas }\end{array}$ \\
\hline 10-Formiltetraidrofolato & $10-\mathrm{CHOH}_{4}$ PteGlu & $-\mathrm{CHO}$ & N10 & $\begin{array}{l}{ }^{*} \text { *íntese de } \\
\text { purinas } \\
\text { *Utilização ou } \\
\text { geração de } \\
\text { formato }\end{array}$ \\
\hline 5,10 Metiltetraidrofolato & $5,10 \mathrm{CHH}_{4}$ PteGlu & $-\mathrm{CH}-$ & $\begin{array}{l}\text { N5- } \\
\text { N10 }\end{array}$ & $\begin{array}{l}{ }^{*} \text { Síntese de } \\
\text { purinas }\end{array}$ \\
\hline $\begin{array}{l}5,10 \\
\text { Metilenotetraídrofolato }\end{array}$ & $5,10 \mathrm{CH}_{2} \mathrm{H}_{4}$ PteGlu & $-\mathrm{CH}_{2-}^{-}$ & $\begin{array}{l}\text { N5- } \\
\text { N10 }\end{array}$ & $\begin{array}{l}\text { *Síntese de } \\
\text { timidalato }\end{array}$ \\
\hline Formiminotetraidrofolato & $\mathrm{CHNHH}_{4}$ PteGlu & $-\mathrm{CHNH}$ & N5 & $\begin{array}{l}{ }^{*} \text { Metabolismo de } \\
\text { histidina }\end{array}$ \\
\hline
\end{tabular}

Nas últimas décadas, o avanço nos conhecimentos tornou evidente que os folatos apresentam uma grande importância para a saúde humana. São 
essenciais como cofatores na síntese de DNA, RNA e neurotransmissores, além de participarem do metabolismo de aminoácidos. Eles também estão presentes na formação e maturação das hemácias e leucócitos (Lima et al., 2003). A ingestão de níveis adequados de folatos é requerida para o metabolismo normal. Os folatos têm papel fundamental no processo de multiplicação celular, sendo, portanto, de suma importância durante a gestação, interferindo no aumento dos eritrócitos, no alargamento do útero e no crescimento da placenta e do feto (Lima-Palonne et al., 2008a; Pontes et al., 2008). São compostos pertencentes ao grupo das vitaminas hidrossolúveis do complexo B9. O termo folato é usado para referir-se aos folatos naturais das plantas e ácido fólico a todas as formas sintéticas ou suplementadas que não estão presentes naturalmente nos alimentos (Melse-Boonstra et al., 2002; Lima et al., 2003).

O Ministério da Saúde do Brasil propôs e a Agência Nacional de Vigilância Sanitária (ANVISA) regulamentou a adição de ácido fólico às farinhas de trigo e milho do Brasil por meio da consulta pública № 51/02. Desde junho de 2004, todas as farinhas de trigo e de milho fabricadas no Brasil ou importadas devem ser enriquecidas com ferro e ácido fólico (Resolução ANVISA - RDC № 344/2002). Cada $100 \mathrm{~g}$ de farinha de trigo e de milho deverá conter 4,2 mg de ferro e $150 \mu \mathrm{g}$ de ácido fólico. Com isso, as farinhas e produtos, como pães, macarrão, biscoitos, misturas para bolos e salgadinhos deverão apresentar maior quantidade de ferro e ácido fólico em sua formulação final (ANVISA; Disponível em: http://www.anvisa.gov.br/legis/index.htm). A biofortificação por engenharia genética ou técnicas de reprodução em plantas oferece uma boa alternativa na luta contra a deficiência de folatos possibilitando o aumento dos níveis desta e de outras vitaminas (Nunes et al., 2009; Blancquaert et al., 2013).

O desenvolvimento de alimentos enriquecidos tem grande importância não só para a indústria de alimentos, como também para elevar a qualidade da alimentação e nutrição da população, possibilitando a ingestão de alimentos com maior valor nutritivo (Frota et al., 2009). Alimentos considerados ricos em folatos são aqueles com mais de $100 \mu \mathrm{g} / 100 \mathrm{~g}$ seguindo atribuições da DFE Dietary Folate Equivalents. As principais fontes de folato são: leite de vaca e 
seus derivados, carnes, ovo de galinha inteiro, hortaliças verde escuro (chicória, brócolis, aspargos, espinafre, couve-de-bruxelas); frutas (banana, cereja fresca, morango, laranja, abacate e frutas cítricas) e grãos de leguminosas (ervilhas, grão de bico, lentilhas, feijão comum, feijão-caupi e soja) (Cozzolino, 2006). Das fontes de folatos chama-se a atenção às leguminosas por conterem altas concentrações de folatos e, portanto, oferecerem a possibilidade de aumentar a ingestão de folatos nas refeições diárias, para isso foi realizado um estudo de teor de folatos das leguminosas dentre elas o feijãocaupi (Rychlik et al., 2007).

Para ajudar a preservar o máximo de folatos dos alimentos, devem-se cozinhar os vegetais apenas levemente e com a menor quantidade de água possível, pois o cozimento prolongado dos alimentos pode destruir até $90 \%$ do seu conteúdo de folato em alimentos naturais e de ácido fólico em alimentos suplementados/fortificados (Nasser et al., 2005). Uma vez que mamíferos não podem sintetizar essa vitamina, é de grande importância seu consumo diário (Cozzolino, 2006). Homens e mulheres a partir de 14 anos de idade, devem ingerir por dia $400 \mu / 100 \mathrm{~g}$ de folatos, dessa forma é possível prevenir as mais diversas doenças (FDA, 1996).

Para mulheres gestantes e em fase de lactação a necessidade nutricional dessa vitamina aumenta para $600 \mu / 100 \mathrm{~g}$ e $500 \mu / 100 \mathrm{~g}$ respectivamente, pois esta fase é caracterizada pelo período de desenvolvimento do embrião no útero, no qual as necessidades nutricionais são elevadas, decorrentes dos ajustes fisiológicos da gestante e das demandas de nutrientes para o crescimento do feto (FDA, 1996; Fonseca, 2003; Penteado, 2003). A ausência de folatos durante o período gestacional pode acarretar malformações fetais, as mais ocorrentes são: (1) anencefalia e espinha bífida - 24-28 dias; (2) lábio leporino - 36 dias; (3) defeitos do septo ventricular cardíaco - 42 dias; (4) fenda palatina - 47 a 72 dias (Thame et al., 1998; Nasser et al., 2005; Paixão et al., 2012). Além da preocupação da deficiência de folatos durante o período gestacional, faz-se necessário atentar para suas demais importâncias como, por exemplo: de seus efeitos preventivos nas doenças cardiovasculares, certas formas de tumores, mal de Alzheimer, 
depressão, cânceres colorretais, pancreático e de mama (Frank \& Soares, 2001; Padilha \& Pinheiro, 2004; Rychlik et al., 2007; Almeida et al., 2012). É importante lembrar que o excesso da ingestão de folatos pode mascarar deficiência de vitamina B12 (Rychlik et al., 2007).

\section{Biossíntese de folatos em plantas}

Os folatos estão presentes em todas as células de plantas, mitocôndrias, plastídios, citoplasma e vacúolos, mas são sintetizados apenas em mitocôndrias (Hanson \& Gregory III, 2014). São co-factores essenciais exigidos não somente pelas plantas, mas também por fungos e bactérias que sintetizam folatos por via metabólica que terminam na adição de glutamatos. (Mc Intosh et al., 2008; Nunes et al., 2009).

Folatos são moléculas formadas por três grupos funcionais: pterina, ácido para-aminobenzoico ( $\mathrm{pABA}$ ) e de um a oito resíduos de glutamato. Em plantas, o resíduo de pterina, hidroximetildihidropteroato (HMDP) é formado a partir de GTP no citosol, enquanto o precursor de pABA é sintetizado no cloroplasto, ambos irão se unir na mitocôndria, ocorrendo subsequentes condensação, glutamilação e redução para a síntese de tetrahidrofolato (Quinlivan et al., 2003; Dellapenna, 2007) (Figura 2).

A conversão de GTP em hidroximetildihidropterina (HMDP) é um processo que ocorre por etapas. A primeira reação é catalisada pela enzima GTP ciclohidrolase 1 (GTPCH1) para formar 7,8-dihidroneopterina trifosfato (DHN-PPP). A enzima dihidroneopterina aldolase pirofosfatase (DHN-PPP) cliva especificamente para produzir dihidroneopterina aldolase monofosfato (DHN-P). Posteriormente, o fosfato remanescente é clivado em dihidroneopterina aldolase (DHN) pela ação de uma fosfatase não específica e o último passo da via das pterinas é catalisado pela dihidroneopterina aldolase (DHN) e dihidromonapteridina (DHM) que são clivadas para originar hidroximetildihidropterina (HMDHP) (Dong et al., 2013).

No cloroplasto, o $p$-aminobenzoato $(\mathrm{pABA})$ é sintetizado a partir do corismato e sequencialmente catalisado pela sintase aminodeoxicorismato 
(ADCS) (Basset et al., 2002). As reações que ocorrem na mitocôndria estão envolvidas da combinação de HMDHP, pABA e glutamato (GLU). Primeiro, HMDHP, é ativada para a sua forma pirofosforilada (HMDHP-PP), depois 0 dihidropteroato é produzido pela condensação de pABA com uma pterina ativada numa reação catalisada pela dihidropteroato sintase. Posteriormente, ocorrem adições de resíduos de glutamato até que se forme o poliglutamato (Figura 2) (Hanson \& Gregory III, 2014).

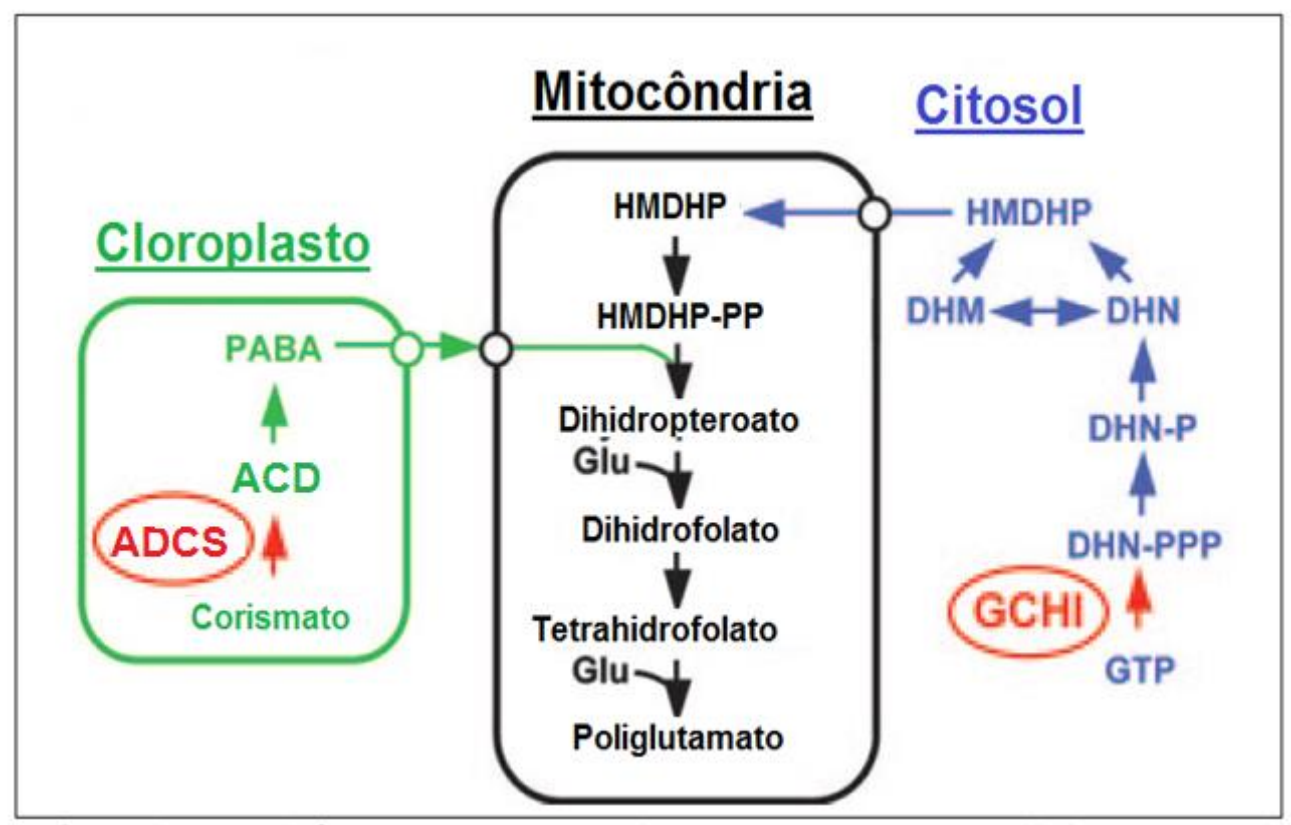

Figura 2: Via de síntese de folato em plantas. As pterinas estão em azul, no citosol ocorre a conversão da guanosina trifosfato (GTP) para hidroximetildihidropterina (HMDHP) através da ação da enzima GTP ciclohidrolase 1 (GTPCH1). A via de síntese de $p$-aminobenzoato é mostrada em verde ocorrendo no cloroplasto, o corismato é convertido em para ácido para-aminobenzoico (pABA) pela ação da enzima aminodeoxicorismato (ADCS). É na mitocôndria que a produção do tetrahidrofolato (THF) acontece. $\mathrm{P}$ refere-se à monofosfato, PP a pirofosfato e PPP a trifosfato (adaptado de Quinlivan et al., 2003).

A via de síntese de folatos em plantas, não é totalmente compreendida, mas a maior parte é provavelmente similar à de bactérias. O gene gch1 em plantas foi descrito primeiramente em dicotiledôneas (Basset et al., 2002). Ele fornece instruções para a produção da enzima GTP ciclohidrolase 1, que é a enzima envolvida na primeira etapa da produção de folatos em plantas, produzindo a pterina (Nunes et al., 2009).

A ação da enzima GTP ciclohidrolase 1 em vias de síntese de folatos que foram investigadas foi encontrada em uma variedade de procariontes e 
eucariontes. Este gene tem sido utilizado na engenharia genética devido a sua importância, pois acredita-se que ele pode estar envolvido com o a taxa de produção de folatos (Mc Intosh et al., 2008).

Os primeiros passos que produzem pterina e pABA são menos conhecidos em plantas, no entanto, dados genômicos mostram que plantas tem uma enzima homóloga a de bactérias na síntese de pterina, a GTP ciclohidrolase $1(\mathrm{GCH} 1)$ e dihineopterina aldalose (DHN). As sequências de resíduos de aminoácidos destas proteínas parecem não possuir sinais de endereçamento para organelas específicas, e por isso são presumivelmente citosólicas (Nunes et al., 2009).

\section{Métodos de quantificação de folatos}

Dentre as principais fontes de folatos, os vegetais podem ser considerados as mais importantes. A grande variação observada nos níveis de folato encontrados nos alimentos pode ser devida aos diferentes métodos de análise utilizados nas determinações (Lima-Pallone et al., 2008b).

Os métodos mais utilizados são: 1) métodos biológicos que avaliam o efeito de dietas pobres em vitaminas sobre os processos fisiológicos de animais de laboratório; 2) métodos microbiológicos que são versáteis e tradicionais para análise de folatos totais, este ensaio é baseado no fato do folato estimular o crescimento de microrganismos láticos, especialmente 0 Lactobacillus casei; a análise microbiológica de folato é aplicável à maioria dos alimentos e a suplementos vitamínicos como se estima que $75 \%$ de ocorrência natural de folatos são poliglutamatos, os quais requerem hidrólise enzimática para detecção de folatos; 3) métodos imunológicos que envolvem procedimentos bioespecíficos, comparativamente, mais rápidos e menos sujeitos a variações, porém ainda é um método novo; 4) métodos cromatográficos são métodos físicos, uma das técnicas mais empregadas é a cromatografia líquida de alta eficiência. Dos métodos utilizados para a quantificação do teor o método microbiológico é o único método reconhecido oficialmente pela Associação Oficial de Químicos Analíticos (AOAC) e pela 
Associação Americana dos Analistas de Cereais (AACC) (Hau, 2008; Cunha, 2013).

\section{Aumento do teor de folatos em plantas por meio de biotecnologia}

Alguns autores definem o melhoramento de plantas de forma clássica como "a ciência e a arte de modificar as plantas para o benefício humano", esta é uma ciência multidisciplinar abrangendo as mais diversas áreas de conhecimento, como: agronomia, botânica, genética molecular, citogenética, fisiologia, patologia, entomologia, bioquímica e estatística (Neto et al., 2008).

A engenharia genética de plantas vem oferecendo novos caminhos a serem seguidos, tornando-se uma das mais importantes ferramentas moleculares no melhoramento vegetal. Nos últimos anos o cultivo de feijãocaupi vem adquirindo maior expressão econômica. Segundo a Companhia Nacional de Abastecimento, referente à safra de 2012-2013, o Brasil produziu 352.000 toneladas, das quais 50.000 toneladas foram exportadas (CONAB, 2014).

Com vista à importância que a cultura de feijão-caupi tem para o país, especialmente nas regiões Norte/Nordeste, faz-se necessário que estudos sejam feitos para a avaliarem a diversidade genética existente em feijão-caupi, visando assim à seleção de genótipos com maiores potenciais produtivos. Esta avaliação da diversidade genética das populações irá permitir o conhecimento das melhores combinações híbridas, viabilizando a obtenção de genótipos superiores nas gerações segregantes (Santos et al., 2014). Alguns parâmetros genéticos são levados em conta, como: coeficiente de variação genético, herdabilidade e correlação entre caracteres. Através deles pode-se conhecer a variabilidade genética, o grau de expressão de um caráter de uma geração para outra e a possibilidade de ganhos por meio da seleção direta ou indireta (Andrade et al., 2010).

Dentre as variedades de genótipos disponíveis, é grande a dificuldade para que se possam escolher as que são mais promissoras como parentais nos programas de hibridação. A escolha das variedades a serem utilizadas é de suma importância, pois quando é feita de forma eficiente leva a economia de 
tempo e de recursos além de potencializar o trabalho (Carvalho, 2011). O melhoramento genético, por demanda dos consumidores, é desenvolver cultivares que associem produtividade com parâmetros de qualidade, como produtos, que tenham maiores teores de vitaminas e minerais. Dessa forma os produtos passam a ser considerados funcionais do ponto de vista da saúde humana (Santos \& Pereira, 2007).

A escolha dos produtos alimentícios para biofortificação dependem dos hábitos alimentares da população, dos aspectos logísticos do processo de biofortificação e a relação química entre o ácido fólico e o produto a ser biofortificado (Alaburda et al., 2007). Em estudo realizado por Bekaert et al., 2007, escolheram o arroz para ser biofortificado e utilizaram genes de Arabidopsis thaliana para superexpressar o gene gch1 e assim aumentar os níveis de folatos na planta. Sementes de arroz transgênicos com superexpressão continham até 100 vezes mais quantidade de folatos, como comparado com o tipo selvagem (1723 contra $17 \mu \mathrm{g} / 100 \mathrm{~g}$ de peso fresco). Estudos com outras cultivares para aumentar os níveis de folatos também foram realizados por Nunes et al., 2009, em que aumentaram a concentração de folatos em plantas geneticamente modificadas de alface pela superexpressão dos genes, GTP ciclohidrolase I e Lycopercicon esculentum corismato sintase. A biofotificação proporcionou um aumento de 2,1 a 8,5 vezes o teor de folatos quando comparada a plantas não transgênicas.

Devido à sua grande importância econômica e nutricional, o feijão-caupi tem sido alvo de programas de melhoramento de muitos diferentes centros de investigação em todo o mundo (Citadin et al., 2011).

Porém os dados relacionados ao teor folato em feijão-caupi ainda são escassos, especialmente para as variedades nacionais. Essa informação é importante para a orientação dos programas de melhoramento genético no sentido de identificar a diversidade existente e transferir essa possível característica para as novas cultivares com alto potencial produtivo. 


\section{JUSTIFICATIVA}

O feijão-caupi é um alimento tradicional muito consumido pelos brasileiros, e por muitos países como, por exemplo, a Nigéria e o Níger, sendo um dos principais componentes de sua dieta alimentar. Os grãos desta leguminosa representam uma importante fonte de proteína, ferro e carboidratos para a dieta humana. Uma grande parcela da população brasileira muitas vezes alimenta-se, basicamente, de feijão com arroz, não tendo acesso a outras fontes de folatos tais como verduras e frutas. Visto a grande importância do consumo de folatos principalmente por mulheres, e a grande ingestão de feijão-caupi pela população mais carente, são necessários estudos sobre a quantidade de folatos existente nestes alimentos mais consumidos, como é caso do feijão-caupi, é importante também o estudo sobre a relação entre a quantidade de folatos e a expressão do gene gch1 nesta cultivar. 


\section{OBJETIVO}

O presente trabalho tem como objetivo a quantificação do teor de folato em 50 genótipos de feijão-caupi [Vigna unguiculata (L.) Walp.], tanto em cultivares tradicionais quanto nas geradas nos programas de melhoramento (Embrapa Meio-Norte). O teor de folatos presente nas sementes será correlacionado com o nível de expressão do gene gch1. 


\section{MATERIAL E MÉTODOS}

\section{Material vegetal}

Foram utilizados 50 genótipos de feijão-caupi, disponibilizados pelo banco de germoplasma da Embrapa Meio-Norte (Piaú́, Brasil), International Institute of Tropical Agriculture (IITA) (Oyo State, Nigéria) e Ahmadu Bello University (Zária, Nigéria) (Tabela 2). As sementes foram plantadas em casa de vegetação para que as plantas se desenvolvessem nas mesmas condições ambientais (solo, luminosidade, temperatura). Durante o desenvolvimento das plantas, sementes imaturas foram coletadas com 10, 15, 20 e 25 dias após a antese e usadas para os estudos de expressão do gene Vugch1.

Também foram coletadas sementes maduras para a quantificação de folatos totais.

Tabela 2: Genótipos de feijão-caupi analisadas para a determinação de teores de folatos totais.

\begin{tabular}{|c|l|}
\hline Número & Genótipos \\
\hline 1 & CE 01 \\
\hline 2 & CE 06 \\
\hline 3 & CE 07 \\
\hline 4 & CE 14 \\
\hline 5 & CE 28 \\
\hline 6 & CE 32 \\
\hline 7 & CE 33 \\
\hline 8 & CE 44 \\
\hline 9 & CE 46 \\
\hline 10 & AM 8.1 \\
\hline 11 & AM 11.2 \\
\hline 12 & AM 12.1 \\
\hline 13 & AM 14.1 \\
\hline 14 & AM 15.1 \\
\hline 15 & AM 21.1 \\
\hline 16 & AM 23.1 \\
\hline 17 & AM 28.1 \\
\hline 18 & AM 33.1 \\
\hline 19 & AM 38.1 \\
\hline 20 & Boca Negra \\
\hline 21 & Nova Era \\
\hline 22 & BR3 Tracuateua \\
\hline 23 & Tvu 2206 meio norte \\
\hline 24 & Xique-Xique \\
\hline 25 & IT 82D 889 \\
\hline 26 & IT 00K 901 - -1 \\
\hline 27 & Pingo de Ouro \\
\hline &
\end{tabular}

\begin{tabular}{|l|l|}
\hline 28 & IT 93K -10 \\
\hline 29 & $\begin{array}{l}\text { Black Eyed Beans } \\
\text { (China) }\end{array}$ \\
\hline 30 & IT 97K - 104- - - 3 \\
\hline 31 & IT 98K 131-2 \\
\hline 32 & Marataoã \\
\hline 33 & Pageú \\
\hline 34 & Tumucumaque \\
\hline 35 & Guariba \\
\hline 36 & Janwake \\
\hline 37 & Kanannado \\
\hline 38 & Karamin Wake \\
\hline 39 & Danrima \\
\hline 40 & Nabebberu \\
\hline 41 & Yarwaja \\
\hline 42 & Azulão \\
\hline 43 & Pitúba \\
\hline 44 & Vita 3 tvu 1190 - \\
\hline 45 & Quênia \\
\hline 46 & Tvu 2331 - chaula \\
\hline 47 & Gempre verde \\
\hline 48 & Frarguéia \\
\hline 49 & Pujante \\
\hline 50 & Itaim \\
\hline
\end{tabular}




\section{Extração de folatos totais de sementes maduras de feijão-caupi}

Sementes maduras foram pesadas em balança de precisão (Balança Analítica Marte - Shimadzu Modelo AY220) e posteriormente foram maceradas manualmente com nitrogênio líquido em cadinho com o auxílio de um pistilo. Foram identificadas e armazenadas em freezer a $-20{ }^{\circ} \mathrm{C}$ até 0 momento das análises.

Coletou-se $1 \mathrm{~g}$ de cada amostra homogeneizada para cada tubo de centrífuga do tipo Falcon $50 \mathrm{ml}$, aos quais foram adicionados $40 \mathrm{ml}$ de tampão fosfato (fosfato de sódio dihidratado 7,8 g/L, ascorbato de sódio $1 \mathrm{~g} / \mathrm{L}$ e pancreatina $250 \mathrm{mg} / \mathrm{L}, \mathrm{pH}$ 7,2); as amostras foram homogeneizadas e incubadas a $37^{\circ} \mathrm{C}$ por $14 \mathrm{~h}$ no escuro. Posteriormente, o material foi incubado em banho-maria a $95^{\circ} \mathrm{C}$ por $30 \mathrm{~min}$, sendo resfriadas rapidamente a $30^{\circ} \mathrm{C}$. Em capela de fluxo laminar, utilizando material esterilizado, foi coletado $1 \mathrm{ml}$ de sobrenadante e transferido para um tubo de centrífuga do tipo Eppendorf o qual foi centrifugado por 5 min a $8.000 \mathrm{~g}$.

Para a preparação do meio de cultura utilizado no método microbiológico quantitativo, foram adicionados ao frasco com meio liofilizado $10 \mathrm{ml}$ de água fornecida pelo kit vita fast. $O$ meio foi homogeneizado e transferido para um tubo do tipo Falcon para em seguida ser levado a banho maria a 95ㅇ $\mathrm{C}$ por 5 min, após esse tempo o meio foi filtrado com filtro de 0,22 $\mu \mathrm{m}$ e transferiu-se para um novo tubo estéril e este ficou armazenado no escuro até o momento em que foi distribuído na placa de microtitulação fornecida pelo kit.

Para o plaqueamento foi utilizada uma placa própria para o experimento, sendo fornecida pelo kit test. Em cada poço aplicou-se $150 \mu \mathrm{l}$ de meio e $150 \mu \mathrm{l}$ da amostra desejada. As amostras foram distribuídas na placa em triplicata biológica. A placa foi vedada com película adesiva do tipo parafilm e incubada a $37^{\circ} \mathrm{C}$ por $48 \mathrm{~h}$ no escuro.

Após o período de $48 \mathrm{~h}$ a placa foi retirada do escuro. A película protetora foi pressionada um pouco, para que fosse possível inverter e agitar a placa de forma a homogeneizar a amostra. A película foi retirada e então a placa foi analisada com o auxílio do software de arquivo de dados, o 4- 
software, com padrões já estabelecidos (padrões, amostras, diluições). A turbidez nos poços foi analisada em espectrofotômetro com filtro de $630 \mathrm{~nm}$.

A partir da leitura da absorbância da bactéria foi possível construir uma regressão polinominal no programa Excel, onde foram cruzados os dados na curva com os dados das amostras, para obter a quantidade de folato equivalente de acordo com o crescimento observado da bactéria.

\section{Clonagem e sequenciamento de fragmentos dos genes da gch1 e alphaEF1.}

A sequência do gene gch1 e de alphaEF1 em feijão-caupi não estavam disponíveis nos bancos públicos e por isso foi necessária uma busca para alinhar várias sequências de outras espécies que estavam disponíveis no banco de dados GenBank. Encontradas estas sequências em outras espécies realizou-se o alinhamento utilizando o programa MEGA (Molecular Evolutionary Genetics Analysis).

Foram encontradas regiões conservadas a partir das quais foi possível desenhar primers para serem utilizados na amplificação de uma região dos genes Vugch1 e alphaEF1 de feijão-caupi. Após a obtenção dos fragmentos por PCR, os fragmentos foram clonados no vetor pGEM-T-Easy (Promega) e posteriormente sequenciados. A partir das sequências encontradas foram desenhados os primers adequados para RT-PCR e qRT-PCR. Os primers alphaEF1 e 18s rRNA foram usados para amplificar os genes de referência.

\section{Extração de RNA de sementes imaturas após antese}

Para a extração de RNA de sementes imaturas $(10,15,20$ e 25 dias após a antese) o protocolo utilizado foi o do kit de extração PureLink ${ }^{\mathrm{TM}}$ Mini Kit da Ambion, seguindo o procedimento: para $200 \mathrm{mg}$ de semente imatura foi adicionado $1 \mathrm{ml}$ de Lysis Buffer $(990 \mu \mathrm{l}$ de Lysis Buffer $+10 \mu \mathrm{l}$ de $\beta$ mercaptoetanol). $O$ material vegetal foi macerado em nitrogênio líquido e transferido para um tubo de microcentrifuga RNAse free contendo o Lysis Buffer. Posteriormente homogeneizado no vortex por $45 \mathrm{seg}$ na velocidade máxima. Depois centrifugou-se a $12.000 \mathrm{~g}$ por $5 \mathrm{~min}$ em temperatura ambiente. 
Após retirar os tubos da centrifuga, o sobrenadante foi removido e transferido para um novo tubo de microcentrifuga RNAse free. A este novo tubo foi adicionado 0,5 volume de etanol $96-100 \%$ para cada volume de tecido homogeneizado e levado ao vórtex para dissolver qualquer precipitado. Nesta etapa foram usados os tubos e colunas fornecidos pelo kit. Foi adicionado na coluna $700 \mu \mathrm{l}$ da amostra e centrifugou-se por $30 \mathrm{seg}$ a $12000 \mathrm{~g} \mathrm{em}$ temperatura ambiente (essa etapa foi realizada duas vezes). Após esta etapa foi adicionado à coluna $700 \mu \mathrm{l}$ de Wash Buffer $\mathrm{l}$, centrifugado a $12000 \mathrm{~g}$ por 15 seg em temperatura ambiente. Descartou-se o que passou e o tubo também. Após essa fase o tubo foi trocado por um tubo novo e na mesma coluna foram adicionados $500 \mu \mathrm{l}$ de Wash Buffer I/ e centrifugado a $12000 \mathrm{~g}$ por $1 \mathrm{~min}$. Repetiu-se esta etapa com as tampas dos tubos abertas para secar o etanol residual. $\mathrm{O}$ que passou pela coluna foi descartado. A coluna foi inserida a um tubo microcentrifuga RNAse free e adicionou-se $30 \mu \mathrm{l}$ de $\mathrm{H}_{2} \mathrm{O}$ RNAse free e centrifugou-se por 2 min a 12000 g. O RNA extraído foi armazenado no -80 C.

\section{RT-PCR}

Após o processo de extração de RNA, os RNAm foram utilizados como molde para a síntese de cDNA. Foi utilizado o kit Super Script ${ }^{T M}$ VILO ${ }^{T M}$ Master Mix da Invitrogen. Os primers utilizados estão na Tabela 3.

Tabela 3: Primers utilizados na análise de RT-PCR.

\begin{tabular}{llc}
\hline Primers & \multicolumn{1}{c}{ Sequências } & Tamanho do Fragmento \\
\hline EF1F & TGTTGCTGTTAAGGATTTGAAGCG & $358 \mathrm{pb}$ \\
EF1R & AACAGTTTGACGCATGTCCCTAAC & $177 \mathrm{pb}$ \\
VuGCH1left & AGCTGAACTTGCCTTTTCTGT & \\
VuGCH1right & TCTGCTTGGTCACCCTTTCT & \\
\hline
\end{tabular}


A reação de RT-PCR foi preparada para um volume final de $20 \mu \mathrm{L}$, contendo $4 \mu \mathrm{L}$ do Super Script ${ }^{T M}$ VILO $^{T M}$ Master Mix, $10 \mu \mathrm{L}$ de RNAm e $6 \mu \mathrm{L}$ de $\mathrm{H}_{2} \mathrm{O}$. Após este processo as reações foram levadas a banho maria por $25^{\circ} \mathrm{C}$ por $10 \mathrm{~min}, 42^{\circ} \mathrm{C}$ por $60 \mathrm{~min}$ e $85^{\circ} \mathrm{C}$ por $5 \mathrm{~min}$. Posteriormente armazenadas em freezer $-20^{\circ} \mathrm{C}$.

A reação de PCR foi feita em um volume final de $25 \mu \mathrm{L}$ utilizando para cada reação $13,55 \mu \mathrm{L}$ de água milliQ autoclavada, $2,5 \mu \mathrm{L}$ de tampão 10x, 0,75 de $\mathrm{MgCl}_{2}, 0,8 \mu \mathrm{L}$ de DNTP's $10 \mathrm{mM}, 0,7 \mu \mathrm{L}$ dos primers senso e antisenso (dois pares diferentes), 0,6 $\mu \mathrm{L}$ de Taq polimerase e $4 \mu \mathrm{L}$ de cDNA. Para a reação de amplificação do DNA foi empregado o programa com um pré-ciclo (desnaturação inicial) a $95{ }^{\circ} \mathrm{C}$ por 5 minutos; 35 ciclos para desnaturação a 95 ${ }^{\circ} \mathrm{C}$ por 1 minuto, anelamento a $55^{\circ} \mathrm{C}$ por 1 minuto e alongamento a $72{ }^{\circ} \mathrm{C}$ por 1 minutos; e um ciclo final de extensão a $72^{\circ} \mathrm{C}$ por 7 minutos. Ao final da reação de PCR, as amostras foram aplicadas em gel de agarose 1,0\%.

\section{qRT-PCR}

Após a realização de RT-PCR foram feitas as análises de qRT-PCR. Esta etapa consistiu-se nas reações de PCR realizadas em um sistema de PCR em tempo real Applied Biosystems 7300 utilizando SyberGreen (Stratagene), de acordo com as instruções do fabricante. O programa utilizado para amplificação consiste em aquecimento a 94ํㅡ por $15 \mathrm{seg}$, seguido por $58^{\circ} \mathrm{C}$ por $15 \mathrm{seg}$ e $72^{\circ} \mathrm{C}$ por $15 \mathrm{seg}$. Foram utilizados os primers listados na tabela 4:

Tabela 4: Lista de primers utilizados na análise de qRT-PCR.

\begin{tabular}{llc}
\hline Primers & \multicolumn{1}{c}{ Sequências } & Tamanho do amplicon \\
\hline 18S rRNAF & TCTTGTGGTGTGGTGTCTTG & $102 \mathrm{pb}$ \\
18S rRNAR & GCATGCTTGACCGTTCGATA & $114 \mathrm{pb}$ \\
EF1F & TGTTGCTGTTAAGGATTTGAAGCG & \\
EF1R & AACAGTTTGACGCATGTCCCTAAC & \\
VuGCH1left & AGCTGAACTTGCCTTTTCTGT & $120 \mathrm{pb}$ \\
VuGCH1right & TCTGCTTGGTCACCCTTTCT & \\
\hline
\end{tabular}


O nível de transcrição relativo à gch1 em diferentes amostras de RNA, foi normalizado em relação aos genes alphaEF1 e 18S rRNA, utilizados como genes de referência. Os primers foram desenhados com o auxílio da ferramenta PrimerQuest Tool (IDT Integrates DNA Technologies, Inc.).

\section{Análise estatística}

A comparação das variedades quanto ao teor de folatos foi realizada através do teste de agrupamento de médias, usando o teste de ScottKnott do programa $R$ v 3.2.3. Os resíduos do modelo foram submetidos à transformação de Boxcox quando não apresentavam normalidade ou homecedascidade da variância. BoxCox, que consiste em transformar os dados de acordo com a expressão: $Y^{\prime}=\left(Y^{\lambda}-1\right) / \lambda$, em que $Y$ é a variável resposta sob investigação e $\lambda$ é um parâmetro a ser estimado dos dados (Box \& Cox, 1964).

Os dados de expressão do gene Vugch1 10, 15, 20 e 25 dias após a antese para cada genótipo estudado foram comparados usando o teste de Duncan do programa Prism v 6.02 (GraphPad Software Inc.). $\mathrm{P}<0,05$ foi considerado como estatisticamente significante. 


\section{RESULTADOS E DISCUSSÃO}

O presente trabalho analisou o teor de folatos em 50 genótipos de feijãocaupi. Estes foram plantados em casa de vegetação, para que as sementes pudessem ser coletadas ainda imaturas para a realização do experimento de qRT-PCR e maduras para o experimento de quantificação do teor de folatos. As sementes imaturas foram coletadas em diferentes dias, sendo 10, 15, 20 e 25 dias a partir da antese e foram armazenadas em geladeira na temperatura de $-80^{\circ} \mathrm{C}$ até $\mathrm{o}$ momento de serem utilizadas no experimento (Figura 3). As sementes utilizadas na quantificação do teor de folatos foram coletas já maduras e acondicionados até o momento de realização do experimento em geladeira, sob temperatura média de $7^{\circ} \mathrm{C}$ desde a sua colheita.

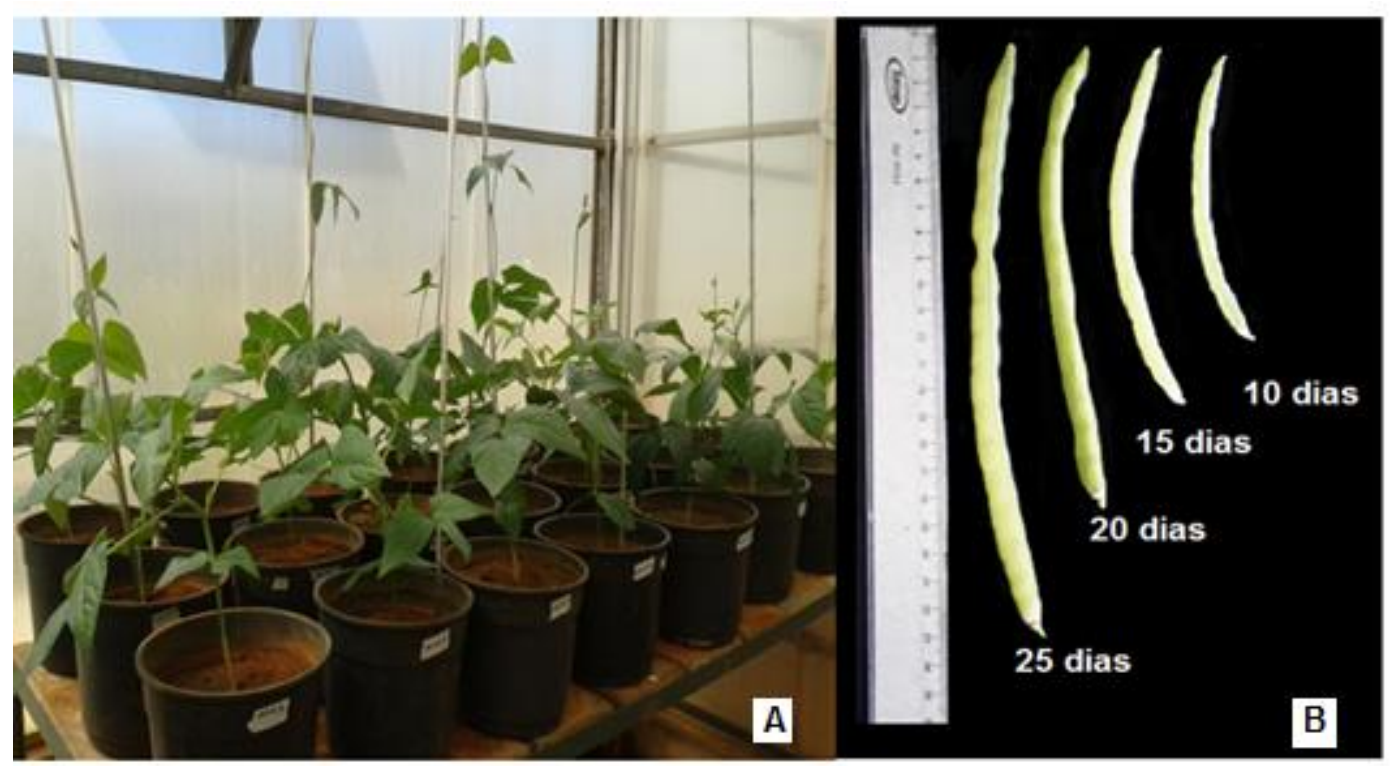

Figura 3: A) cultivares em fase de desenvolvimento para posteriormente gerarem as vagens a serem coletadas nos diferentes dias de maturação após a antese. B) vagens em diferentes dias de maturação sendo contados a partir dos dias de desenvolvimento após a antese.

\section{Quantificação do teor de folatos em feijão-caupi}

Para o experimento de quantificação do teor de folatos foram utilizadas sementes já maduras secas, que foram plantadas em casa de vegetação, cultivadas e coletadas sob as mesmas condições de iluminação, temperatura e preparo de solo. Foi utilizado um teste microbiológico por meio do kit vita fast 
da R-Biopharm AG, o princípio desse ensaio microbiológico baseia-se na medida de turbidez da solução, o crescimento do microrganismo depende da quantidade de folatos presente na amostra, sendo que este crescimento é proporcional à turbidez do meio, a bactéria utilizada foi a Lactobacillus casei. Com a obtenção dos dados, fez-se uma análise estatística que gerou a tabela 5 , a qual demonstra a diferença no teor de folatos entre as 50 variedades estudadas.

Para quantificar os folatos biodisponíveis da matriz celular de sementes de feijão-caupi foi utilizada a pancreatina de galinha de forma a transformar os poliglutamatos em monoglutamatos e assim tornar possível a realização experimento de quantificação do teor de folatos. Esta mesma metodologia foi utilizada em experimentos com sementes de trigo coletadas 20, 30 e 40 dias após a antese, mostrando que com os passar dos dias de coleta houve um decréscimo nos níveis de folatos totais de aproximadamente 30\%. Em trigo esse decréscimo ocorreu 30 dias após a antese quando ocorreu o final do enchimento dos grãos (Mc Intosh et al., 2008). As análises de quantificação do teor de folatos gerou a tabela 5 .

Tabela 5: Análise do teor de folato ( $\mu \mathrm{g}$ de folato / $100 \mathrm{~g}$ de semente) em 50 genótipos de feijão caupi.

\begin{tabular}{cr}
\hline Variedade & Teor de Folato \\
\hline Yarwaja & \\
Azualão & $780,75 \pm 178,61 \mathrm{a}$ \\
AM 33.1 & $610 \pm 21,49 \mathrm{a}$ \\
AM 12.1 & $610,5 \pm 77,62 \mathrm{a}$ \\
Tvu 2331 - Chaula & $579,75 \pm 33,94 \mathrm{a}$ \\
Itaim & $571,25 \pm 87,24 \mathrm{a}$ \\
AM 14.1 & $557,75 \pm 7,41 \mathrm{a}$ \\
CE01 & $550 \pm 55,06 \mathrm{a}$ \\
Pujante & $547,5 \pm 28,55 \mathrm{a}$ \\
Nabbereru & $552,25 \pm 114,27 \mathrm{a}$ \\
Vita3 tvu 1190 - Quênia & $538,25 \pm 33,29 \mathrm{a}$ \\
Kanannado & $532 \pm 49,99 \mathrm{a}$ \\
Pitúba & $545,5 \pm 144,04 \mathrm{a}$ \\
AM 28.1 & $525,5 \pm 65,90 \mathrm{a}$ \\
Guariba & $525,25 \pm 101,22 \mathrm{a}$ \\
& $514,5 \pm 13,30 \mathrm{a}$
\end{tabular}


AM 15.1

Gurguéia

Sempre verde

AM 8.1

Janwake

CE 28

CE06

AM 21.1

IT 98k 131 -2

CE 33

CE 07

BR 3 Tracuateua

IT $93 \mathrm{~K}-10$

CE 14

Nova Era

Karamin Wake

Black Eyed Beans

(China)

Fradinho CB 27

AM 38.1

Pegeú

Boca Negra

Tvu 2206 meio norte

AM 23.1

CE 32

IT 82D- 889

CE 44

Danrima

Tucumumaque

AM 11.2

CE 46

Marataoã

IT 00K 901 - 5-1

Xique- xique

IT 97k - 104- 2 -3

Pingo de Ouro
$512,75 \pm 49,73$ a

$509 \pm 71,94^{a}$

$499 \pm 88,55$ a

$484 \pm 78,40$ a

$509,5 \pm 211,20$ a

$496,25 \pm 173,25 \mathrm{~b}$

$460,5 \pm 11,70 \mathrm{~b}$

$466 \pm 92,09 b$

$462,75 \pm 88,92 \mathrm{~b}$

$472,5 \pm 129,93 \mathrm{~b}$

$451,5 \pm 60,69 b$

$458,5 \pm 77,05 \mathrm{~b}$

$446 \pm 126,59 \mathrm{~b}$

$430,5 \pm 35,60 \mathrm{~b}$

$446,25 \pm 131,51 \mathrm{~b}$

$428,25 \pm 40,24 b$

$419,75 \pm 37,21$

$419,5 \pm 61,87 \mathrm{~b}$

$413 \pm 23,41 b$

$427 \pm 130,29 \mathrm{~b}$

$419 \pm 88,45 \mathrm{~b}$

$421,75 \pm 125,16 \mathrm{~b}$

$403 \pm 36,72 b$

$408,5 \pm 134,38$ b

$411,5 \pm 155,65 \mathrm{~b}$

$374,5 \pm 70,17 b$

$389,75 \pm 145,52$ b

$364 \pm 20,46 b$

$352 \pm 22,24 \mathrm{~b}$

$340 \pm 4,90 \mathrm{~b}$

$288 \pm 26,98 \mathrm{c}$

$281,5 \pm 25,89 \mathrm{c}$

$276,5 \pm 19,96 \mathrm{c}$

$281 \pm 42,41 \mathrm{C}$

$177 \pm 9,38 d$

Médias ( \pm desvio padrão) seguidas da mesma letra não diferem estatisticamente pelo teste Scott \& Knott, ao nível de 5\% de probabilidade. 
Ao nível de $5 \%$ de significância, o teste de Scott \& Knott mostra que as variedades devem ser considerados em 4 grupos distintos (Tabela 4). $O$ modelo conseguiu explicar $92,10 \%$ da variabilidade total dos dados (SQResiduos=0.033, SQvariedade $=0.105, \quad F_{49,150}=9.546, p$-valor $=<2 e-16$ ). Nesse caso, os dados necessitaram ser transformados (Box-Cox, $\lambda=-0.41$ ).

Nossos resultados demonstram que houve uma variação de 177 a $780 \mu \mathrm{g} / 100 \mathrm{~g}$, para a verificação da expressão do gene gch1, a cultivar que apresentou maior teor de folatos foi uma cultivar africana a Yarwaja $(780 \mu \mathrm{g} /$ 100 g). Em estudos com feijão comum, Melse-Boonstra et al., (2002) encontraram uma concentração de folatos totais variando de a 100 a $540 \mu \mathrm{g} /$ $100 \mathrm{~g}$. Comparando os resultados encontrados no presente estudo com os valores de folatos da base de dados do Departamento de Agricultura dos Estados Unidos - USDA (2013) que eram de $394 \mu \mathrm{g} / 100 \mathrm{~g}$ para feijão comum, observa-se que, no geral, os teores de folatos totais foram mais altos na maioria das variedades de feijão-caupi analisadas por este trabalho.

$\mathrm{Na}$ literatura é possível encontrar quantificação do teor de folatos em sementes de feijão-caupi, utilizando um método microbiológico com a bactéria Streptococcus faecalis, que variam de 137 a $186 \mu \mathrm{g} / 100 \mathrm{~g}$ para 30 diferentes cultivares (Ogunmodede \& Oyenuga, 1970), não foi possível fazer maiores comparações entre as cultivares utilizadas com os nossos resultados, pois os autores utilizaram o número de acesso e não os nomes das cultivares estudadas. Foi possível, entretanto, verificar que as amostras de feijão-caupi analisadas neste trabalho apresentaram concentração da vitamina muito superior em relação às determinações de folatos no mesmo alimento.

Em estudo realizado por Rychlik et al., (2007), em que foi analisado o teor de folatos em diferentes leguminosas obteve-se os seguintes resultados para diferentes variedades de feijões verdes frescos (Phaseolus vulgaris), ervilhas verdes frescas (Pisum sativum), o teor de folatos variou de 78 a $87 \mu \mathrm{g} /$ $100 \mathrm{~g}(78$ e $87 \mu \mathrm{g} / 100 \mathrm{~g}$, respectivamente). Produtos secos como ervilhas frescas (Pisum sativum), grão de bico (Cicer arietinum); lentilhas verdes e vermelhas (Lens culinaris), soja (Glycine max) houve uma variação no teor de folatos de 154 a $318 \mu \mathrm{g} / 100 \mathrm{~g}(154,178$ e $318 \mu \mathrm{g} / 100 \mathrm{~g}$, respectivamente). Produtos enlatados feijão branco, feijão preto e feijão (Phaseolus vulgaris); 
feijão mungo (Vigna radiata); feijão-fradinho (Vigna unguiculata); feijão-deporco (Canavalia ensiformis); e amendoim (Arachis hypogaea). O teor de folatos variou de 94 a $277 \mu \mathrm{g} / 100 \mathrm{~g}(164,106,182,277,152,94$ e $94 \mu \mathrm{g} /$ $100 \mathrm{~g}$, respectivamente). Nas análises realizadas em nosso trabalho o feijão fradinho apresenta teor de folatos de $419 \mu \mathrm{g} / 100 \mathrm{~g}$ sendo um teor maior que o encontrado nas analises de Rychlik et al., (2007), foi de $152 \mu \mathrm{g} / 100 \mathrm{~g}$.

Para que um alimento seja considerado rico em teor folatos ele deve conter pelo menos a seguinte proporção $100 \mu \mathrm{g} / 100 \mathrm{~g}$, segundo o estudo realizado é possível constatar que as variedades analisadas atingem esse teor. Os folatos estão presentes em muitos alimentos inclusive no feijão-caupi, porém é fácil a ocorrência de deficiência dessa vitamina, devido a sua grande sensibilidade ao calor, luz e oxigênio (Citadin et al., 2013, Pontes et al., 2008). Quando os alimentos forem preparados, deve-se atentar as altas temperaturas pois estes podem vir a perder alguns nutrientes e vitaminas importantes. Devido ao fator de sensibilidade ao calor, luz e oxigênio as amostras analisadas foram manuseadas na ausência de luz em alguns momentos do experimento, como por exemplo, ficar no escuro por $48 \mathrm{~h}$ dessa forma perderíamos o mínimo de vitaminas como é o caso dos folatos.

Em estudos realizados com outras cultivares, que não são leguminosas, encontrou-se variações nos níveis de folatos em alho poró de 80 a $570 \mu \mathrm{g} / 100$ g. Em estudos com couve flor encontraram 240 a $650 \mu \mathrm{g} / 100 \mathrm{~g}$ e em espinafre foram encontrados variações de 225,8 a 527,3 $\mu \mathrm{g} / 100 \mathrm{~g}$ e de 52 a 117,4 $\mu \mathrm{g} /$ $100 \mathrm{~g}$, para espinafres crus e cozidos, respectivamente (Lima-Pallone et al., 2008a). É possível observar uma variação significativa no teor de folatos para um mesmo alimento no qual a comparação realizada foi entre espinafres crus e cozidos. Outro estudo em que é possível observar uma diferença significativa no teor de folatos foi realizado com brócolis no qual se comparou o teor de folatos entre o brócolis convencional e o orgânico, obtendo respectivamente os seguintes valores 413,7 a $742,2 \mu \mathrm{g} / 100 \mathrm{~g}$ e 954,0 a 1739,7 $\mu \mathrm{g} / 100 \mathrm{~g}$ (LimaPallone et al., 2008b). 


\section{Obtenção de fragmentos dos genes gch1 e alphaEF1 de $V$. unguiculata}

Para que fossem possíveis as análises de RT-PCR e qRT-PCR, primeiramente fez-se uma busca do gene gch1 em Vigna unguiculata e não foram encontradas sequências depositadas no GenBank. Com isso, foi feito o alinhamento de algumas espécies que tinham a sequência do gene depositado no banco de dados e através destas foi possível montar a que foi utilizada no estudo. As sequências utilizadas foram das espécies: Arabidopisis thaliana, Glycine max, Lycopersicon esculentum, Phaseolus vulgaris e Solanum lycopercium. Com as sequências depositadas foram construídos primers degenerados em regiões conservadas para cada um dos dois genes (gch1 e alphaEF1) e com isso foi amplificado um fragmento. $O$ fragmento então foi clonado no PGEM-T Easy e posteriormente sequenciado. Os dados obtidos então foram depositados no Genbank. Estas sequências foram denominadas de Vigna unguiculata GTP cyclohydrolase 1 (gch1) mRNA (número de acesso: KM886567.1) partial cds e Vigna unguiculata elongation factor 1-alpha (ef1-a) mRNA, partial CDs (número de acesso: KM886568.1), conforme mostram os anexos 1 e 2 respectivamente.

\section{qRT-PCR}

A reação de amplificação em tempo real é uma variante da reação de PCR convencional. Esta por sua vez representa um grande avanço nos métodos moleculares, particularmente por facilitar sobremaneira as tarefas de quantificação da expressão gênica em determinado amostra biológica ou tecido biológico (Ladeira et al., 2011). Para realização do qRT-PCR primeiramente foi necessário a realização de um RT-PCR, fez-se a extração do RNAm, de modo que a enzima transcriptase reversa sintetizasse o cDNA correspondente de cada fita de RNA.

Dos 50 genótipos utilizados no experimento utilizou-se nessa parte do experimento apenas 5 diferentes genótipos: AM 14.1, BR3 Tracuateua, CE 06, Guariba e Pitúba. O resultado obtido com o RT-PCR foi então confirmado com 
os resultados do qRT-PCR em que havia maior nível de expressão do gene gch1 em sementes de 20 dias após a antese (Figura 4).

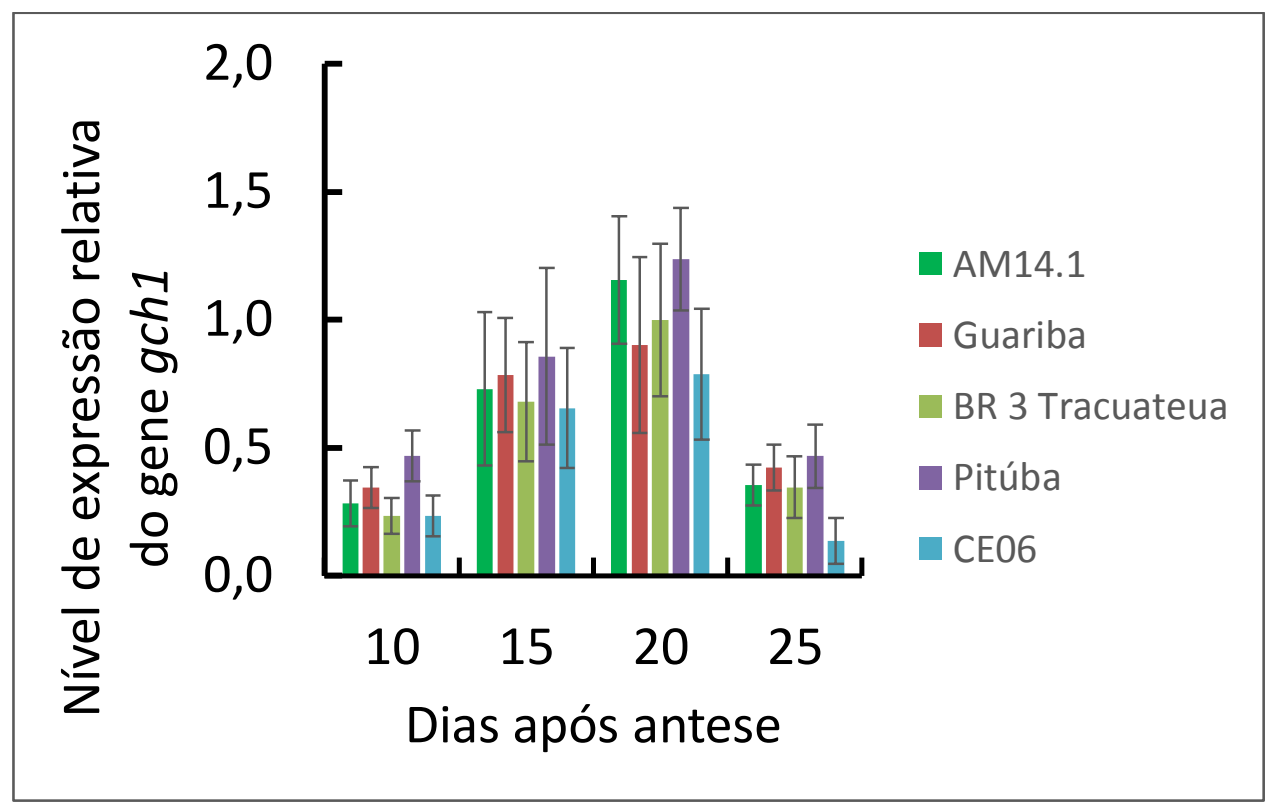

Figura 4: Nível de expressão relativa do gene gch1 em sementes imaturas de 5 cultivares de feijão-caupi 10, 15, 2025 dias após a antese. A comparação entre as médias observadas em cada dia, para uma mesma cultivar, mostrou serem estatisticamente diferentes, exceto os dias 15 e 20 para CE06 $(P<0,05 ; n=3)$.

Após a confirmação de qual era o pereíodo com maior expressão do gene gch1 realizou-se outra análise de qRT-PCR contendo todos os 50 genótipos estudados usando somente as sementes coletadas com 20 dias após a antese. Foi observado que quando se compara o teor total de folatos com o nível de expressão do gene gch1 é detectado a existência de um padrão semelhante entre as cultivares (Figura 5).

A realização dessa análise possibilitou à conclusão de que o dia em que as sementes imaturas de feijão-caupi possuem maior expressão do gene gch1 é em 20 dias após a antese. Hefni et al., (2015) relataram em seu estudo que o conteúdo de folatos no feijão-fava (Vicia faba L.) que há perda significativa de até $70 \%$ de feijão-fava verde para estágio seco. Concluindo que à medida que a vagem amadurece as sementes tem uma queda na produção do gene gch1 e consequentemente

no

teor

de

folatos. 

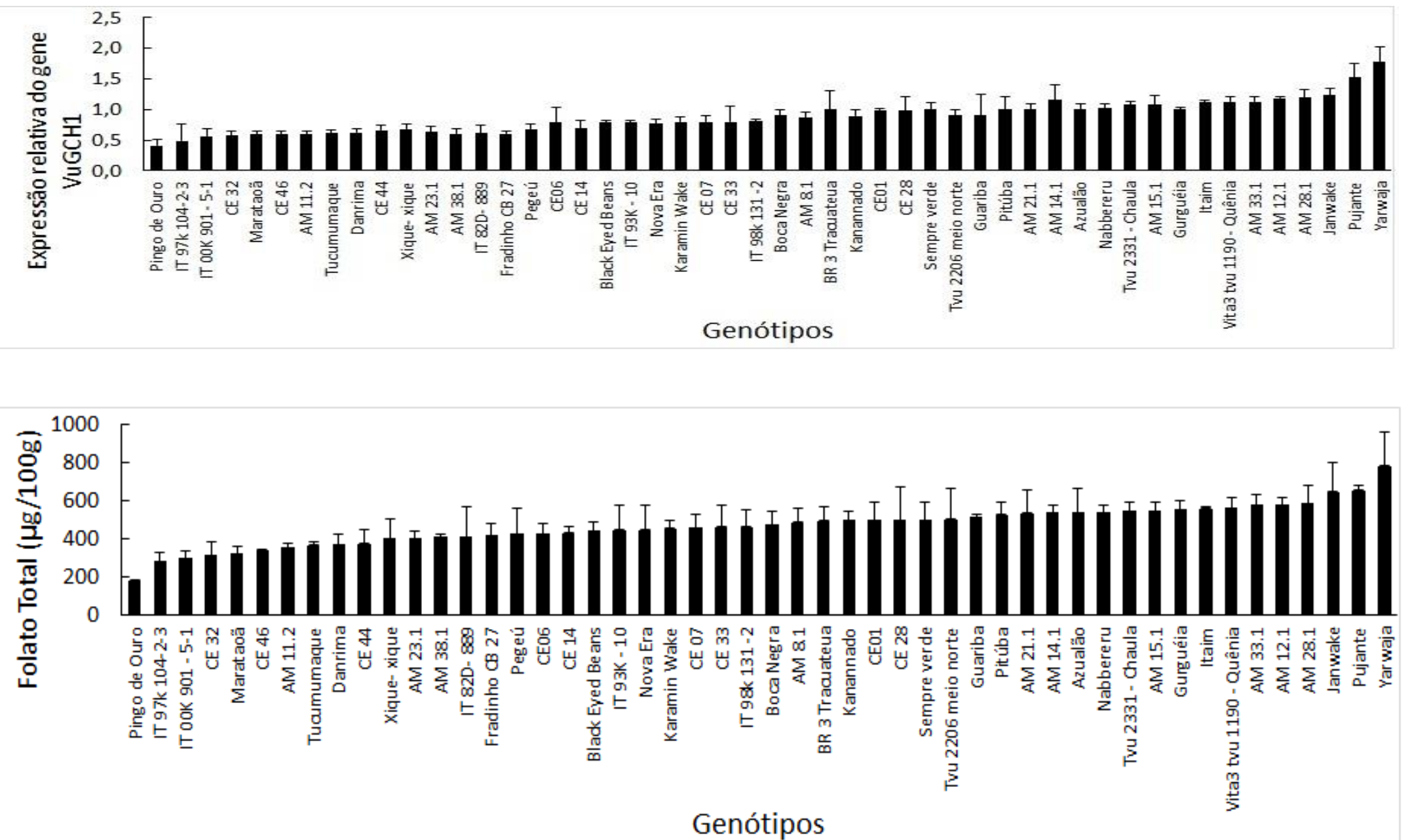

Figura 5: Expressão relativa do gene Vugch1 em sementes de 50 genótipos de feijão-caupi 20 dias após a antese (gráfico superior) e teores de folatos totais em sementes maduras (gráfico inferior). Média \pm erro padrão $(n=9)$. 


\section{Correlação da expressão do gene gch1 com o teor de folatos}

À medida que se aumenta o teor de folatos também aumenta o nível de expressão do gene mostrando que estão correlacionados o teor de folatos com a expressão do gene gch1 (Figura 6). De acordo com Lima et al.; 2003, as quantidades de folatos encontradas nos vegetais estão intimamente ligadas ao grau de maturação do vegetal, pois o processo de divisão celular ocorre na maior parte em tecido mais jovens e essa quantidade de folatos é menor em tecidos já maduros.

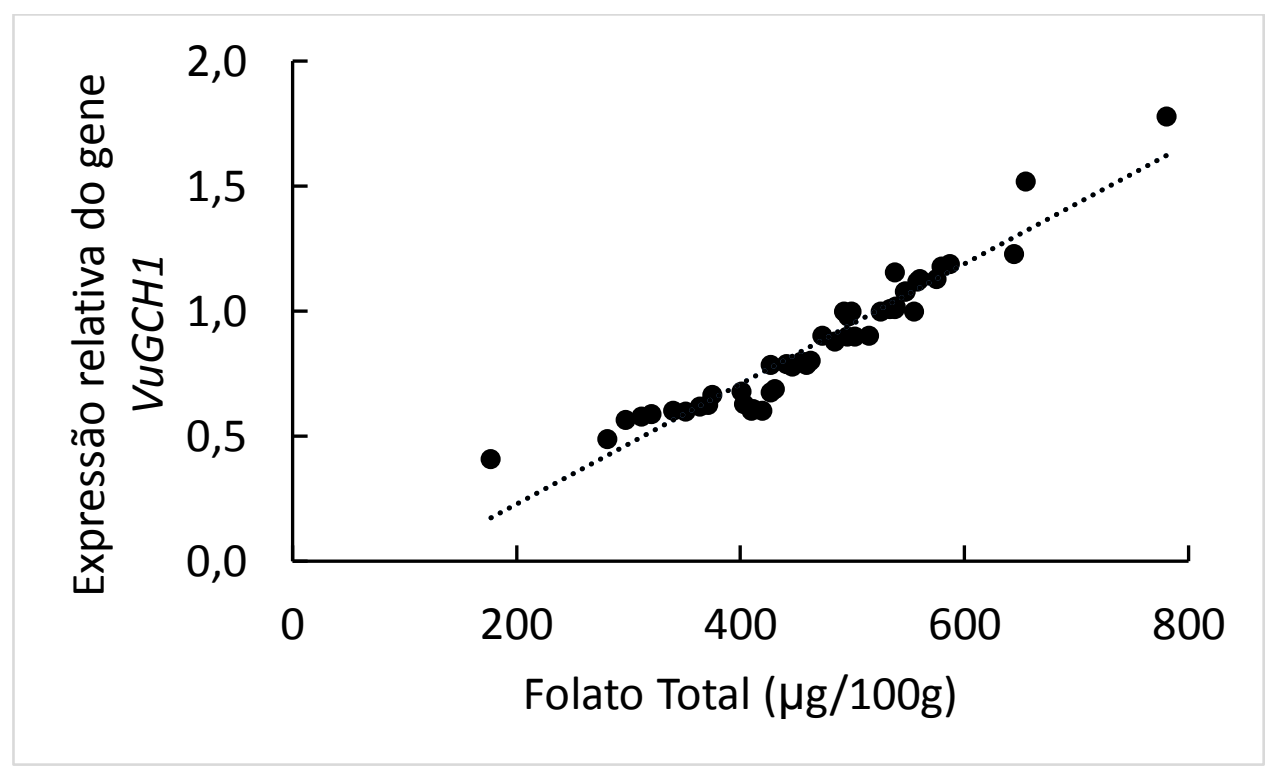

Figura 6: Análise da correlação entre o nível de expressão do gene gch1 e a quantidade de folatos totais em sementes imaturas com 20 dias após a antese. Coeficiente de correção linear $=0,955$.

É evidenciado uma maior expressão do gene Vugch1 em sementes que se encontram verdes. Após esta fase nota-se um íngreme declínio no nível de expressão de Vugch1, quando então os níveis de folatos também começam a diminuir, implicando em um colapso da capacidade da semente para manter a sua maquinaria na síntese de folatos, e, portanto, para sustentar seus níveis de folatos (Basset et al., 2002). Estudos com gch1 sintéticos foram realizados a fim de observar a relação do gene gch1 e a produção de folatos. Em estudos com tomate no qual foi superexpresso o gene gch1 de mamífero obteve-se 
uma elevação da produção de pteridina de 3 a 140 vezes o conteúdo de folatos (De La Garza et al., 2004). Já em estudos para biofortificação de alface foi utilizado o gch1 de galinha e observou-se um aumento de 2,1 a 8,5 vezes no conteúdo de folatos (Nunes et al., 2009). 


\section{CONCLUSÃO E PERSPECTIVA}

Neste trabalho foram avaliados 50 genótipos de feijão-caupi, que é uma leguminosa rica em muitos nutrientes importantes para a saúde e bem-estar do ser humano, dentre estes, o folato que é uma vitamina hidrossolúvel pertencente ao complexo B.

Tendo em vista a necessidade do consumo de folatos para homens e mulheres em todas as faixas etárias e também o grande consumo de feijãocaupi pela população, principalmente de baixa renda, é de grande relevância o estudo de quantificação de folatos nesta leguminosa.

A ingestão diária de folatos é de suma importância e alimentar-se de grãos ricos nesta vitamina é fundamental. Em nosso estudo, foi possível constatar que a cultivar tradicional africana Yarwaja apresenta alto nível de folatos, isto é $780 \mu \mathrm{g} / 100 \mathrm{~g}$ de semente, o que é um resultado satisfatório quando comparada a outras cultivares de feijão-caupi aqui testadas e também com outros resultados encontrados na literatura para a mesma espécie.

Demonstrou-se também, uma correlação entre o nível de expressão de Vugch1 e o aumento no teor de folatos, corroborando a hipótese inicial na qual quanto maior a expressão do gene Vugch1 maior a quantidade no teor de folatos em sementes imaturas, isso é, com 20 dias após a antese.

Este estudo tem uma grande importância para nortear futuros estudos de programas de melhoramento genético no feijão-caupi com o objetivo de tornar esta leguminosa ainda mais rica em folatos e que seja uma alternativa acessível para estar na mesa de todos os brasileiros suprindo as necessidades diárias desta vitamina. Com a variabilidade para esse caráter, os programas de melhoramento podem lançar mãos dos genótipos mais adequados para gerar novas variedades com características agronômicas desejáveis e com maior teor de folatos. 


\section{REFERÊNCIAS BIBLIOGRÁFICAS}

ALABURDA, J.; SHUNDO, L. 2007. Ácido fólico e fortificação de alimentos. Revista do Instituto Adolfo Lutz, v.66, n.2, p.95-102.

ALMEIDA, C. C.; BRENTANI, H. P.; FORLENZA, O. V.; DINIZ, B. S. 2012. Redução dos níveis séricos de ácido fólico em pacientes com a doença de Alzheimer. Revista Psiquiatria Clínica, v.39, n.3, p.90-93.

ALVES, J. M. A.; UCHOA, S. C. P.; SILVA, A. J.; NASCIMENTO, J. F.; LIMA, A. C. S.; ALBUQUERQUE, J. A. A.; SILVA L. C.; BARBOSA, R. N. T.; FILHO, C. A. T.; BARROS, M. M.; RODRIGUES, G. S. 2007. Programa de melhoramento do feijão-caupi da UFRR. Workshop sobre a Cultura do Feijãocaupi em Roraima -Embrapa. p.41- 47.

ANDRADE JÚNIOR, A. S.; BARROS, A. H. C.; SILVA, C. O.; FREIRE FILHO, F. R. 2007. Zoneamento de risco climático para a cultura do feijão-caupi no Estado do Ceará. Revista Ciências Agrônomas, v.38, n.1, p.109-117.

ANDRADE, F. N.; ROCHA, M. M.;GOMES, R. L. F., FEREIRE FILHO, F. R.; RAMOS, S. R. R. 2010. Estimativas de parâmetros genéticos em genótipos de feijão-caupi avaliados para feijão fresco. Revista Ciência Agronômica, v.41, n.2, p.253-258.

ANVISA - Agência Nacional de Vigilância Sanitária. (Acessado em 14/11/2012). Disponível em: http://www.anvisa.gov.br/legis/index.htm.

BEKAERT, S.; STOROZHENKO, S.; MEHRSHAHI, P.; BENNETT, M. J.; LAMBERT, W.; GREGORY III, J. F.; SCHUBERT, K.; HUGENHOLTZ, J.; STRAETEN, D. V. D.; HANSON, A. D. 2008. Folate biofortification in food plants. Trend in Plant Science. p.1360-1385 
BASSET, G., QUINLIVAN, E. P.; ZIEMAK, M. J., DE LA GARZA, R. D.; FISCHER, M.; SCHIFFMANN, S., BACHER, A.; GREGORY, J. F.; HANSON, A. D. 2002. Folate synthesis in plants: The first step of the pterin branch is mediated by a unique bimodular GTP cyclohydrolase I. Proceedings of the National Academy of Sciences, v.99, n.19, p.12489-12494.

BLANCQUAERT, D.; STOROZHENKO, S.; DAELE. V. J.; STOVE, C. V.; RICHARD G. F.; LAMBERT, W.; STRAENT, D. D. V. 2013. Enhancing pterin and para-aminobenzoate content is not sufficient to successfully biofortify potato tubers and Arabidopsis thaliana plants with folate. Journal of Experimental Botany, v.64, n.12, p.3899-3909.

BOX, G. E. P.; COX, D. R. 1964. An analysis of transformations (with discussion). Journal of the Royal Statistical Society B, v.26, p.211-252.

CARVALHO, L. C. B. 2011. Cruzamentos dialélicos visando à obtenção de populações produtivas e biofortificadas para os teores de ferro, zinco é proteína em feijão-caupi. Dissertação. Faculdade de Genética e Melhoramento do Piauí.

CITADIN, C. T.; IBRAHIM, A. B.; ARAGÃO, F. J. L. 2011. Genetic engineering in Cowpea (Vigna unguiculata): History, status and prospects. Genetically Modified Crops, v.2, n.3, p.144-149.

CITADIN, C. T.; CRUZ, A. R. R.; ARAGÃO, F. J. L. 2013. Development of transgenic imazapyr-tolerant cowpea (Vigna unguiculata). Plant Cell Report, v. 32, p.537-543.

COZZOLINO, S. M. F. 2006. Biodisponibilidade de nutrientes. Revista Brasileira de Ciências Farmacêuticas, v.41, n.1, p.385-399.

CONAB - Companhia Nacional de Abastecimento (Acessado em 26/04/2016). Disponível em: http://www.conab.gov.br/. 
CRAVO, M. S.; SOUZA, B. D. L. 2007. Workshop sobre a Cultura do FeijãoCaupi em Roraima -Embrapa. Sistemas de cultivo do feijão-caupi na Amazônia, p.17-25.

CUNHA, E. C. E. 2013. Feijões- folatos: uma revisão. Dissertação (Ciência de Alimentos) Faculdade de Engenharia de Alimentos da Universidade Estadual de Campinas.

DE LA GARZA, R. D.; QUINLIVAN, E. P.; KLAUS, S. M. J.; BASSET, G. J. C.; JESSE, F.; GREGORY III, J. F.; HANSON, A. D. 2004. Folate biofortification in tomatoes by engineering the pteridine branch of folate synthesis. Proceedings of the National Academy of Sciences, v.101, n.38, p.13720-13725.

DELLAPENNA, D. 2007. Biofortification of plant-based food: Enhancing folate levels bymetabolic engineering. Proceedings of the National Academy of Sciences of the USA, v.104, n.10, p.3675-3676.

DONG, W.; CHENG, Z. X. U. J.; ZHENG, T.; WANG, X.; ZHANG, H.; WANG, J.; WAN, J. 2013. Identification of QTLs underlying folate content in milled rice. Journal of Interative Agriculture, p.1-10.

FDA. 1996. Food standards: amendment of standards of identity for enriched grain products to require addition of folic acid. Federal Register, v.61, n.44. p.8781-8791.

FONSECA, V. M. 2003. Consumo de folato em gestantes de um hospital público do Rio de Janeiro. Revista Brasileira de Epidemiologia, v.6, n.4, p.319327.

FRANK, A. A.; SOARES, E. A. 2001. Folic acid for the prevention of chronic degenerative disorders in elderly. Journal of the Brazilian Society for Food and Nutrition, v.21, p.103-120. 
FREIRE FILHO, F. R.; RIBEIRO, V. Q.; BARRETO, P. D.; SANTOS, A. A. 2005. Melhoramento genético. In: Freire Filho F. R. et al. (Ed.) Feijão caupi: avanços tecnológicos. Editora Embrapa Informação Tecnológica, p.29-92.

FREIRE FILHO, F. R.; VILARINHO, A. A.; CRAVO, M. S.; CAVALCANTE, E. S. 2007. Panoramo da cultura de feijão-caupi no Brasil. Workshop sobre a Cultura do feijão-caupi em Roraima - Embrapa, p.10-16.

FREIRE FILHO, F. R.; RIBEIRO, V. Q.; ROCHA, M. M.; SILVA, K. J. D.; NOGUEIRA, M. S. R.; RODRIGUES, E. V. 2011. Feijão-Caupi no Brasil Produção, melhoramento genético, avanços e desafios. Embrapa Meio-Norte Teresina, p.10-80.

FROTA, K. M. G.; MORGANO, M. A.; SILVA M. G.; MOTA ARAÚJO, M. A. M.; MOREIRA-ARAÚJO, R. S. R. 2009. Utilização da farinha de feijão-caupi (Vigna unguiculata L. Walp) na elaboração de produtos de panificação. Ciência e Tecnologia de Alimentos, p.1-7.

IVO, N. L.; NASCIMENTO, C. P.; VIEIRA, L. S.; CAMPOS, F. A. P.; ARAGÃO, F. J. L. 2008. Biolistic-mediated genetic transformation of cowpea (Vigna unguiculata) and stable Mendelian inheritance of transgenes. Plant Cell Report. p.1-9.

HANSON, A.; GREGORY III, J. F. 2014. Folate Biosynthesis, Turnover, and Transport in Plants. Annual Review of Plant Biology, v.61, p.105-125.

HAU, R. 2008. The analysis and stability of microencapsulated folic acid during the processing and preparation of instant Asian noodles. PhD thesis, RMIT University: Melbourne, p.204.

HEFNI, M. E.; SHLABY, M. T.; WITHCOFT, C. M. 2015. Folate content in faba beans (Vicia faba L.) - effects of cultivar, maturity stage, industrial processing, and bioprocessing. Food Science \& Nutrition, v.3, n.1, p.65-73. 
KRISHNASWAMY, K.; MADHAVAN, N. K. 2001. Importance of folate in human nutrition. British journal of nutrition, v.85, n.2, p.15-24.

LADEIRA, P. R. S.; ISAAC, C.; FERREIRA, M. C. 2011. Reação em cadeia da polimerase da transcrição reversa em tempo real Real-time reverse transcription polymerase chain reaction. Revista Médica, v.90, n.1, p.47-51.

LIMA, J. A.; CATHARINO, R. R.; GODOY, H. T. 2003. Folatos em vegetais: Importância, efeito do processamento e biodisponibilidade. Alimentos e Nutrição Araraquara, v.14, n.1, p.123-129.

LIMA-PALLONE, J. A.; CATHARINO, R. R.; GODOY, H. T. 2008a. Folatos em brócolis convencional e orgânico e perdas no processo de cocção em água. Química Nova, v.31, n.3, p.530-535.

LIMA-PALLONE, J. A.; CATHARINO, R. R.; GODOY, H. T. 2008b. Determinação de folatos em espinafre - avaliação da influência do tipo de cultivo, época de colheita e cozimento. Archivos Latino Americanos de Nutrcion, v.58, n.1, p.81-86.

MELO, R. A.; FORTI, V. A.; CíCERO, S. M.; NOVEMBRE, A. D. C. L.; MELO, P. C. T. 2010. Use of X-ray to evaluate damage caused by weevils in cowpea seeds. Horticultura Brasileira, v.28, n.4, p.472-476.

MELSE-BOONSTRA, A.; VERHOEF, P.; KONINGS, E. J. M.; DUSSELDORP, M. V.; MATSER, A.; HOLLMAN, P. C. H.; MEYBOOM, S.; KOK, F. J.; WEST, C. E. 2002. Influence of processing on total, monoglutamate and polyglutamate folate contents of leeks, cauliflower, and green beans. Journal of Agricultural and Food Chemistry, v.50, p.3473-3478.

MENEZES, A. C. S. G.; ZILLI, J. E.; VILARINHO, A. A.; GALVÃO, A.; MESSIAS, O. I.; MELO, V. F. 2007. Importância socioeconômica e condições 
de cultivo do feijão-caupi em Roraima. Workshop sobre a Cultura do Feijãocaupi em Roraima -Embrapa. p.26-35.

Mc INTOSH, S. R., BRUSHETT, D., HENRY, R. J. 2008. GTP cyclohydrolase 1 expression and folate accumulation in the developing wheat seed. Journal of Cereal Science, v.48, p.503-512.

NASSER, C.; NOBRE, C.; MESQUITA, S.; RUIZ, J. G.; CARLOS, H. R.; PROUVOT, L.; YACUBIAN, E. M. T. 2005. Semana da conscientização sobre a importância do ácido fólico. Journal of Epilepsy and Clinical Neurophysiology, v.11, n.4, p.199-203.

NETO, A. L. F.; RIBEIRO JÚNIOR, W. Q.; FALEIRO, F. G. 2008. A sociedade Brasileira de Melhoramento de Plantas - Regional DF. Pré-melhoramento, melhoramento e pós-melhoramento: estratégias e desafios. Embrapa. p.19-28.

NEVES, A. L. R.; LACERDAL, C. F.; GUIMARÃES, F. V. A.; HERNANDEZ, F. F. F.; PRISCO, F. B. J. T.; GHEYI, H. R. 2009. Acumulação de biomassa e extração de nutrientes por plantas de feijão-de-corda irrigadas com água salina em diferentes estádios de desenvolvimento. Ciência Rural, v.39, n.3, p.758765.

NUNES, A. C. S.; KALKMANN, D. C.; ARAGÃO, F. J. L. $2009 . \quad$ Folate biofortification of lettuce by expression of a codon optimized chicken GTP cyclohydrolase I gene. Transgenic Research, v.18, p.661-667.

OGUNMODEDE, B. K.; OYENUGA, V. A. Vitamin B contente of cowpeas (Vigna Unguiculta ta Walp) II. Pyridoxine, pantothenic acid, biotin and folk acid. 1970. Journal of the Science of Food and Agriculture, v.21, p.87-91. 
PADILHA, P. C.; PINHEIRO, R. L. 2004. O papel dos alimentos funcionais na prevenção e controle do câncer de mama. Revista Brasileira de Cancerologia. v.50, n.3, p.251-260.

PAIXÃO, G. P. N.; SENA, C. D.; SANTOS, T. C. S.; GOMES, N. P.; CARVALHO, M. R. S. 2012. The importance of the use of folic acid and ferrous sulfate by women during pregnancy: a comprehensive literature review. Revista Atenção Primária a Saúde. v.15, n.2, p.214-219.

PASSOS, A. R.; SILVA, S. A.; CRUZ, P. J.; ROCHA, M. M.; CRUZ, E. M. O.; ROCHA, M. A. C.; BAHIA, H. F.; SALDANHA, R. B. 2007. Divergência genética em feijão-caupi. Bragantia, v.66, n.4, p.579-586.

PENTEADO, M. D. V. 2003. Vitaminas, Aspectos nutricionais, bioquímicos, clínicos e analíticos. Revista Brasileira de Ciências Farmacêuticas, v.39, n.1, p. 487-492.

PONTES, E. L. B.; PASSONI, C. M. S.; PAGANOTTO, M. 2008. The importance of the folic acido $\mathrm{n}$ pregnancy: Requeriment and biodisponibility. UniBrasil - cadernos da Escola de Nutrição, n.1, p.1-6.

QUINLIVAN, E. P.; ROJE, S.; BASSET, G.; SHACHAR-HILL, Y.; GREGORY III, J. F.; HANSON, A. D. 2003. The folate precursor p-Aminobenzoate is reversibly converted to its glucose ester in the plant cytosol. The Journal of Biological Chemistry, v.278, n.23, p.20731-20737.

RYCHLIKA, M.; ENGLERT, K.; KAPFER, S. KIRCHHOFF, E. 2007. Folate contents of legumes determined by optimized enzyme treatment and stable isotope dilution assays. Journal of Food Composition and Analysis, v.20, p.411419. 
SANTOS, L. M. P.; PEREIRA, M. Z. 2007. Efeito da fortificação com ácido fólico na redução dos defeitos do tubo neural. Caderno de Saúde Pública, v. 23, n.1, p.17-24.

SANTOS, J. A. S.; TEODORO, P. E.; CORREA, A. M.; SOARES, C. M. G. S.; RIBEIRO, L. P.; ABREU, H. K. A. 2014. Desempenho agronômico e divergência genética entre genótipos de feijão-caupi cultivados no ecótono Cerrado/Pantanal. Bragantia, v. 73, n. 4, p.377-382.

SILVA, R. T. L.; ANDRADE, D. P.; MELO, E. C.; PALHETA, E. C. V.; GOMES, M. A. F. 2011. Inoculação e adubação mineral na cultura do feijão-caupi e latossolos da Amazônia oriental. Revista Caatinga, v.24, n.4, p.52-15.

THAME, G.; SHINOHARA, E. M. G.; SANTOS, H. G.; MORON, A. F. 1998. Folate, Vitamin B12, Serum Ferritin and Defects of the Neural Tube. Revista Brasileira de Ginecologia e Obstetrícia, v. 20, n. 8, p. 449-453.

UCHOA, S. C. P.; ALVES, J. M. A.; SILVA, A. J.; MELO, V. F; LOPES, G. N.; IVANOFF, M. E.; CRUZ, D. L. S.; JUNIOR, H. O. A. 2007. Aspectos de fertilidade do solo para a cultura do feijão-caupi. Workshop sobre a Cultura do Feijão-caupi em Roraima -Embrapa. p.48-53.

VÁSQUEZ, A. O.; SUAREZ-OBANDO, F.; SUAREZ-OBANDO, V. 2015. Defectos del tubo neural y del ácido fólico: recorrido histórico de una intervención preventiva altamente efectiva. História, Ciências, Saúde Manguinhos, v.22, n.4, p.1157-1172.

VILARINHO, A. A.; FREIRE FILHO, F. R. 2005. Avaliação de genótipos de Feijão-caupi de porte ereto no estado de Roraima. Roraima: Embrapa Roraima (Embrapa Roraima. Comunicado Técnico, 8), p.8. 


\section{ANEXO 1 - referente a Vigna unguiculata elongation factor 1-alpha (ef1-a) mRNA, partial CDs (número de acesso GenBank: KM886568.1)}

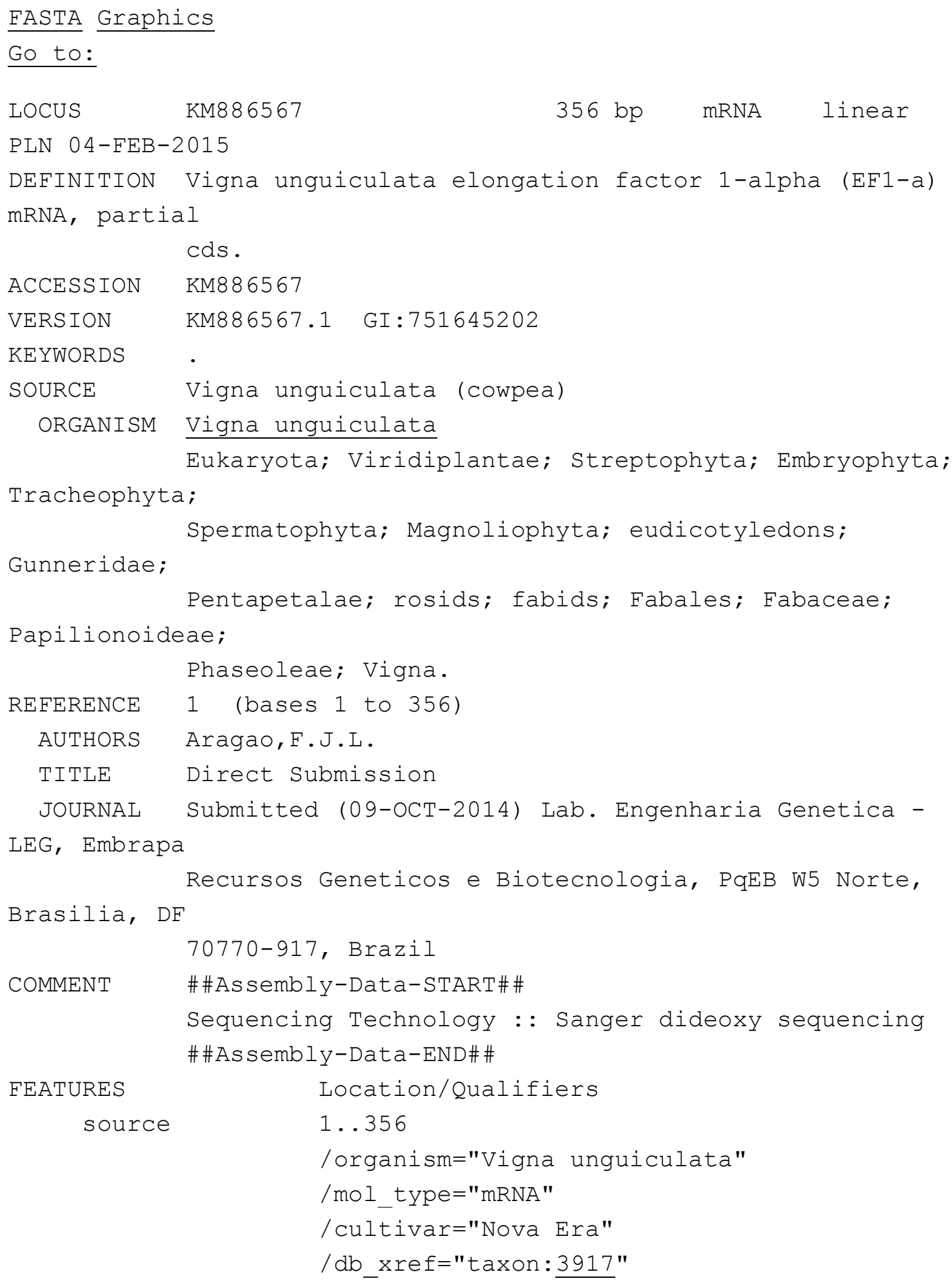


gene

$<1 . .>356$

/ gene="EF1-a"

CDS

$<1 \ldots>356$

/ gene="EF1-a"

/ codon_start $=1$

/product="elongation factor 1-alpha"

/protein_id="AJF94634.1"

/db_xref="GI : $751645203 "$

/translation="VAVKDLKRGFVASNSKDDPAKEAANFTSQVI IMNHPGQI GNGYA PVLDCHTSHIAVKFAELVTKIDGRSGKELEKEPKFLKNGDAGFVKMIPTKPMVVETFS EYPPLGRFAVRDMRQTV"

ORIGIN

1 gttgctgtta aggatttgaa gcgtggtttc gttgcatcca actccaagga tgaccctgcc

61 aaggaagctg ccaacttcac atcccaagtc atcatcatga accatcctgg ccagatcgga

121 aacggctatg caccagtgct cgattgccac acttcccaca ttgcagtgaa gttcgccgag

181 cttgtcacca agatcgacgg gcgatcaggt aaggagctgg agaaggagcc caaatttttg

241 aagaatggtg atgcaggttt cgttaagatg attccaacca agcccatggt ggttgaaacc

301 ttctctgagt atcctcccet tggtcgtttt gccgttaggg acatgcgtca aactgt // 


\section{ANEXO 2 - referente a Vigna unguiculata GTP cyclohydrolase 1 (gch1) mRNA (número de acesso GenBank: KM886567.1)}

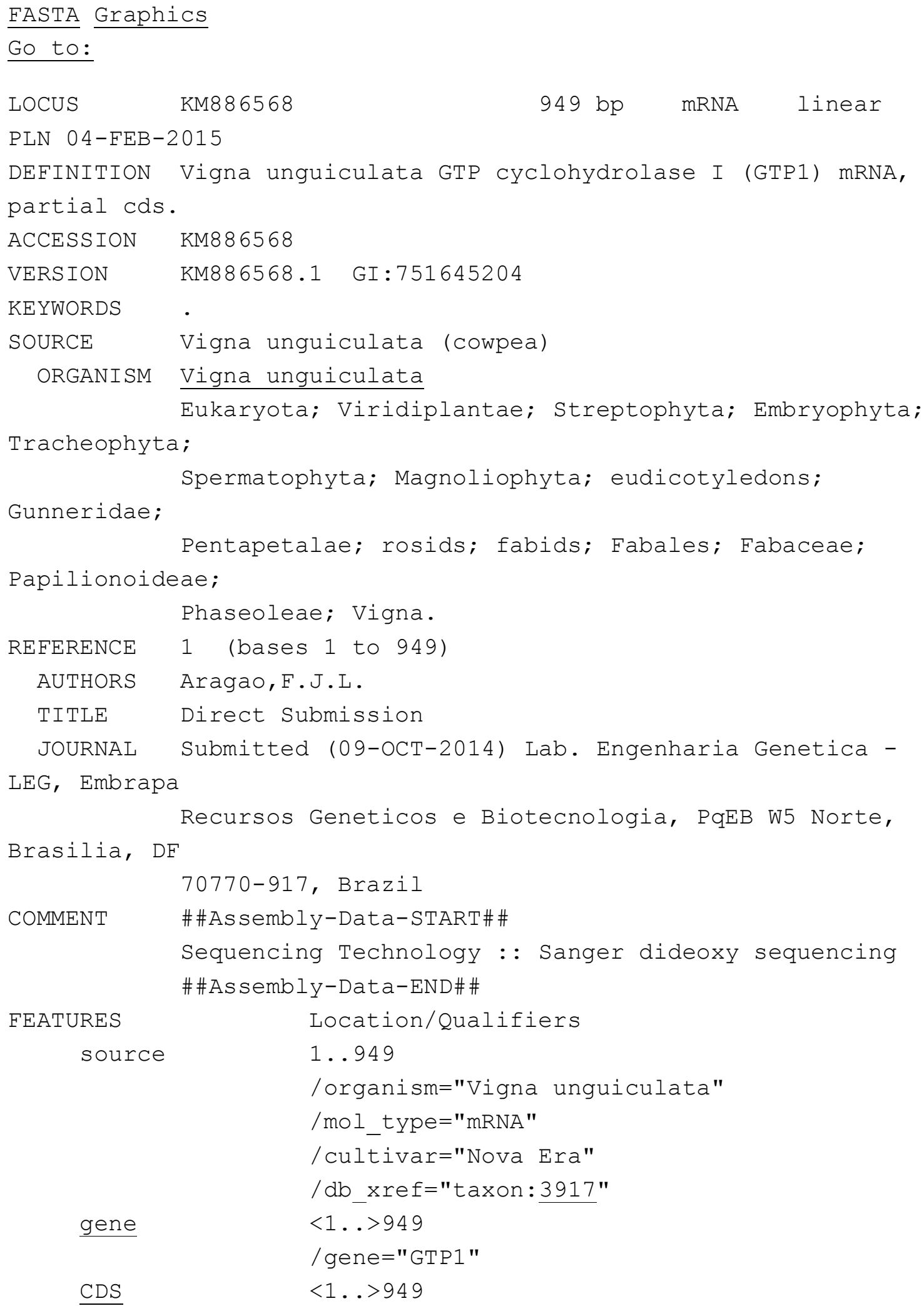




$$
\begin{aligned}
& \text { /gene="GTP1" } \\
& \text { /codon_start=1 } \\
& \text { /product="GTP cyclohydrolase I" } \\
& \text { /protein_id="AJF94635.1" } \\
& \text { /db_xref="GI: } 751645205 "
\end{aligned}
$$

\section{/translation="CESCLLPFYFKCHVGYVPSAQRVLGLSKLSRVTNVFAKRLQEPQ RLANEVCSALHEGIQPTGVAVVLQCKHI PFPDMESNSLGSNHKGVVGI LVSSGSGVFE NKDANLWADFFGLLNFRG IDKDKILDKGSMDDQCWCPS LSSKVSSENEELNPAMLTAV AS ILKSLGEDPTRKELEGTPARYTKWLMNFKCSS IERALNCWLGIRTNGALNTNEGLG FDEKLHSE LNLPFLSQCEHHLLPFHGVVHI GYFVSKGFHP IEKSLLQS IVHFYGI KLQ VQERVTKQIAETISPLIGGNVIVVVEASHTCMISRGIEKF"}

ORIGIN

1 tgtgagtctt gcttgcttcc attctatttc aagtgccatg tggggtatgt cccttctgcc 61 caaagagttc tcggtttaag caaactctct cgtgtcacca atgtgtttgc aaaacgtctc 121 caagaacctc aaagacttgc aaatgaggtg tgttctgctt tgcatgaagg aattcaaccc 181 acaggtgttg ctgttgtgct tcaatgcaaa cacattccet ttccagacat ggaatcaaac 241 tctcttggct caaaccacaa aggagtggtg gggatactgg tttcttcagg ctccggtgtt 301 tttgaaaaca aagatgcaaa cttgtgggct gacttttttg gcctccttaa ctttagaggc 361 attgacaagg acaaaattct tgataagggg tcaatggacg accaatgttg gtgtccttct 421 ttgtcttcta aagtctcatc cgagaatgaa gagctgaacc ctgctatgct cactgcagta 481 gcttcaattc tcaagtcttt aggcgaggat ccaactagga aggaattaga agggactcct 541 gctaggtata ccaaatggct gatgaacttc aagtgtagta gcattgagag ggcgctgaat 601 tgttggcttg ggattcggac aaatggtgct ttgaacacta atgaggggtt aggttttgat 661 gaaaagctac actcagagct gaacttgcct tttctgtcac agtgtgagca tcatttgctt 721 ccatttcatg gtgttgttca cataggatac ttcgtttcca aagggtttca tcccattgag 781 aaaagcttgt tgcagtcaat agtgcatttt tatggtatta agctgcaggt tcaagaaagg 841 gtgaccaagc agattgcaga aactatttcc ccattgattg gtggaaatgt gatagtagtg 901 gtggaagcaa gtcacacatg catgatttct cggggaattg agaagtttg 